OPEN ACCESS

Edited by:

Manoj Prasad,

National Institute of Plant Genome

Research, India

Reviewed by:

Charu Lata

National Botanical Research Institute

(CSIR), India

Kalyan B. Babu,

Indian Council of Agricultural

Research, India

Robert VanBuren,

Michigan State University, USA

${ }^{*}$ Correspondence:

Kevin M. Murphy

kmurphy2@wsu.edu

Specialty section:

This article was submitted to Plant Genetics and Genomics,

a section of the journal

Frontiers in Plant Science

Received: 15 September 2016 Accepted: 12 December 2016 Published: 09 January 2017

Citation: Habiyaremye $C$, Matanguihan $J B$,

D'Alpoim Guedes J, Ganjyal GM,

Whiteman MR, Kidwell KK and

Murphy KM (2017) Proso Millet

(Panicum miliaceum L.) and lts Potential for Cultivation in the Pacific

Northwest, U.S.: A Review.

Front. Plant Sci. 7:1961

doi: 10.3389/fpls.2016.01961

\section{Proso Millet (Panicum miliaceum L.) and Its Potential for Cultivation in the Pacific Northwest, U.S.: A Review}

\author{
Cedric Habiyaremye', Janet B. Matanguihan', Jade D'Alpoim Guedes², \\ Girish M. Ganjyal ${ }^{3}$, Michael R. Whiteman ${ }^{4}$, Kimberlee K. Kidwell ${ }^{5}$ and Kevin M. Murphy ${ }^{1 *}$
}

\begin{abstract}
'Sustainable Seed Systems Lab, Department of Crop and Soil Sciences, College of Agricultural, Human, and Natural Resource Sciences, Washington State University, Pullman, WA, USA, ${ }^{2}$ Department of Anthropology, Washington State University, Pullman, WA, USA, ${ }^{3}$ Food Processing Lab, School of Food Science, College of Agricultural, Human, and Natural Resource Sciences, Washington State University, Pullman, WA, USA, ${ }^{4}$ International Programs, International Research and Agricultural Development, Washington State University, Pullman, WA, USA, ${ }^{5}$ College of Agricultural, Consumer, and Environmental Sciences, University of Illinois, Urbana, IL, USA
\end{abstract}

Proso millet (Panicum miliaceum L.) is a warm season grass with a growing season of 60-100 days. It is a highly nutritious cereal grain used for human consumption, bird seed, and/or ethanol production. Unique characteristics, such as drought and heat tolerance, make proso millet a promising alternative cash crop for the Pacific Northwest (PNW) region of the United States. Development of proso millet varieties adapted to dryland farming regions of the PNW could give growers a much-needed option for diversifying their predominantly wheat-based cropping systems. In this review, the agronomic characteristics of proso millet are discussed, with emphasis on growth habits and environmental requirements, place in prevailing crop rotations in the PNW, and nutritional and health benefits. The genetics of proso millet and the genomic resources available for breeding adapted varieties are also discussed. Last, challenges and opportunities of proso millet cultivation in the PNW are explored, including the potential for entering novel and regional markets.

Keywords: proso millet, Pacific Northwest, alternative crops, diversification, nutrition and health benefits, genetics

\section{INTRODUCTION}

\section{Worldwide Significance of Millets}

Millets are small-seeded annual cereals grown for food, feed, forage, and fuel (Rachie, 1975; Kothari et al., 2005). About 20 different species of millet have been cultivated throughout the world at different points in time (Fuller, 2006). Commonly cultivated millet species include proso millet (Panicum miliaceum L.), pearl millet (Pennisetum glaucum L.R. Br.), finger millet (Eleusine coracana), kodo millet (Paspalum setaceum), foxtail millet (Setaria italica L. Beauv.), little millet (Panicum sumatrense), and barnyard millet (Echinochloa utilis) (Rachie, 1975; Bouis, 2000; Wen et al., 2014). Millet ranks sixth among the world's most important cereal grains, sustaining more than one-third of the world's population (Verma and Patel, 2012; Changmei and Dorothy, 2014). Asian and African countries are the biggest millet producers (Table 1; Figure 1). Millets are a major

Abbreviations: ATP, Adenosine triphosphate; BP, before present time; CDA, Colorado Department of Agriculture; CVD, cardiovascular disease; GDD, Growing Degree Day; PNW, Pacific Northwest; WSU, Washington State University. 
TABLE 1 | Top five millet producers in the world, 2014.

\begin{tabular}{ll}
\hline Country & Production [t] \\
\hline India & $11,420,000$ \\
Niger & $3,321,753$ \\
China & $1,780,000$ \\
Mali & $1,715,044$ \\
Nigeria & $1,384,900$ \\
\hline
\end{tabular}

Source: FAOSTAT, 2014 (http://faostat3.fao.org/browse/Q/QC/E)

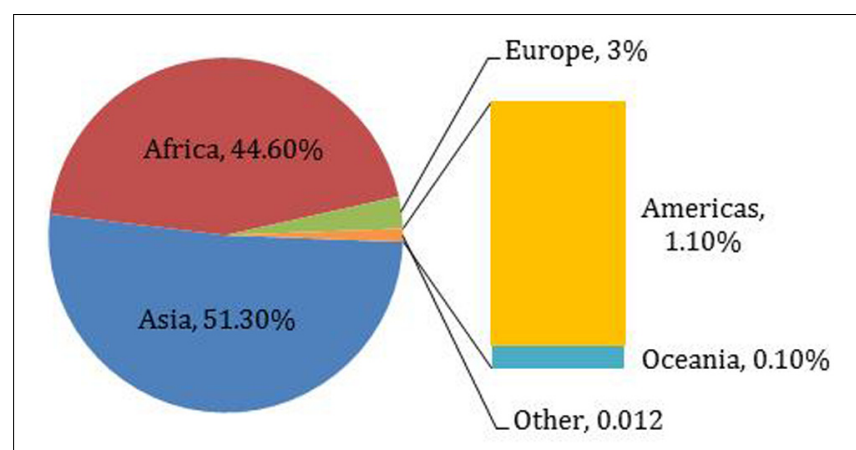

FIGURE 1 | Worldwide millet production by region, 2014.

source of energy and protein for millions of people in China, Japan, Africa, and India, and especially for people living in hot and dry areas of the world (Rachie, 1975; Amadou et al., 2013).

Millets are generally among the most suitable crops for sustaining agriculture and food security on marginal lands with low fertility. Millet crops are grown on marginal lands and under low-input agricultural conditions-situations in which major cereal crops often produce low yields (Amadou et al., 2013). Millet can be productive even under harsh growing conditions, especially in regions such as India and Sub-Saharan and West Africa, where average rainfall is often less than $500 \mathrm{~mm}$ and soils are sandy and slightly acidic (Changmei and Dorothy, 2014). Of all the millets cultivated in Africa, 74\% are grown in SubSaharan and West Africa, accounting for $28 \%$ of the world's production (Changmei and Dorothy, 2014). Drought and lack of irrigation are permanent constraints to agricultural production in many developing countries, and are occasional causes of yield loss in developed countries (Ceccarelli and Grando, 1996). An efficient strategy for producing crops under water-deficient conditions is to grow crops adapted to drought instead of crops that require more water (Seghatoleslami et al., 2008). Since millets are adapted to drought conditions, they can be keystone crops to avert food shortage and famine (Amadou et al., 2013).

\section{Domestication and Spread of Proso Millet}

Proso millet was likely domesticated in China sometime around 10,000 BP. Current archeological theorists believe that proso millet domestication took place around the beginning of the Holocene as global temperatures became warmer and huntergatherers were exposed to new plants and environments
(Bettinger et al., 2007, 2010a,b). A wild ancestor for proso millet has yet to be identified (Miller et al., 2016); however, weedy forms of millet, which may include a wild progenitor, are found across Eurasia (Zohary et al., 2012). Chromosomal in situ hybridization with genomic DNA and phylogenetic data provide evidence of the allotetraploid origin of proso millet, with Panicum capillare or a close relative, and Panicum repens as ancestors (Hunt et al., 2014).

Although archeologists have yet to agree on the exact timing of millet domestication, they generally agree that domestication likely took place separately in three different centers: (1) Northwest China (Bettinger et al., 2007, 2010a,b), (2) Central China (Lu et al., 2009), and (3) Inner Mongolia (Zhao, 2005). From these centers of domestication, millet spread widely throughout East Asia, including high-altitude areas such as the Tibetan Plateau. By the end of the 2nd millennium BP, the cultivation of proso millet had spread to the rest of Central Eurasia and to Eastern Europe (Miller et al., 2016). However, during the 4th millennium BP, worldwide temperatures became cooler (Marcott et al., 2013), and may have led to difficulties in millet cultivation. Evidence shows major shifts in proso millet farming on the Tibetan Plateau until its cultivation was abandoned in Eastern Tibet (Guedes et al., 2014, 2015a,b; Chen et al., 2015; Guedes, 2015). Later, proso millet was largely replaced by wheat and barley on the Tibetan Plateau; however, it continued to be a popular crop in low-lying plains of northern China well after its introduction (Boivin et al., 2012). Warming temperatures in the Himalayan region today may allow farmers to cultivate millet in this area once more. By the fifth millennium BP, proso millet cultivation appears to have spread to Kazakhstan (Frachetti et al., 2010) and Pakistan (Weber, 1991), but whether this crop was grown in these countries before this time is unclear. Site evidence for several finds of proso millet in these areas dates to as early as 8000-7000 BP (Hunt et al., 2008).

\section{Growth and Environmental Requirements}

Proso millet is a summer annual grass, most frequently grown as a late-seeded summer crop (Rao, 1989; Baltensperger, 2002; Williams et al., 2007), and can complete its life cycle within 60-100 days (Baltensperger, 2002). A compact panicle droops at the top like an old broom, hence proso millet's common name, "broom corn" (Changmei and Dorothy, 2014). Grains are round, about $3 \mathrm{~mm}$ long and $2 \mathrm{~mm}$ wide, and enclosed in a smooth hull, which is typically white or creamy-white, yellow, or red in color, but may be gray, brown, or black. White-seeded varieties are most often grown in the U.S., followed by red-seeded varieties (Hardman, 1990; Baltensperger, 2002; Williams et al., 2007; Changmei and Dorothy, 2014). Proso millet ranges from 30 to $100 \mathrm{~cm}$ tall, with few tillers and an adventitious root system (Baltensperger, 2002).

Proso millet grows further north than the other millets (up to $54^{\circ} \mathrm{N}$ latitude) and is well adapted to plateau and high-elevation conditions. For example, the plant is found up to $1200 \mathrm{~m}$ in the mountains of the former Union of Soviet Socialist Republics (USSR) and up to $3500 \mathrm{~m}$ in India (Baltensperger, 2002). Proso millet also grows under non-irrigated conditions in arid lands with as little as $200-500 \mathrm{~mm}$ of average annual precipitation 


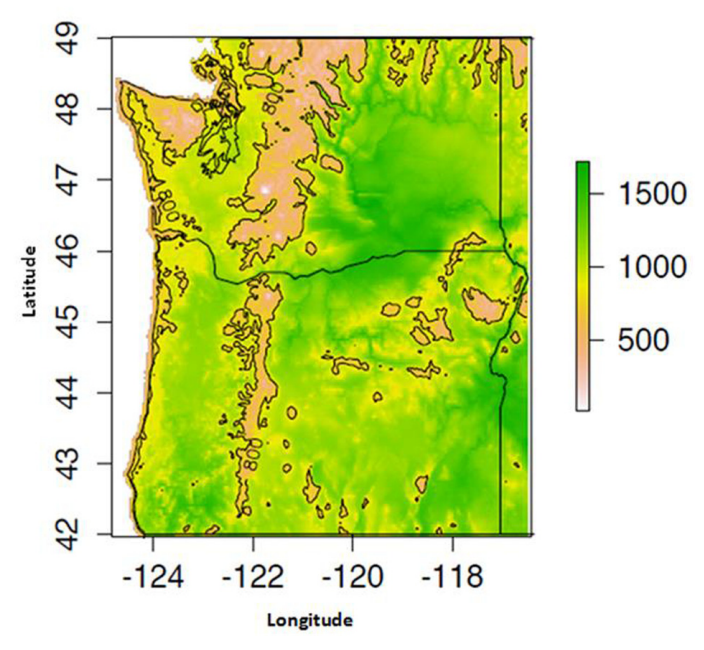

FIGURE 2 | Mean May-September growing degree day (GDD) availability for the years 1981-2014, computed using $800 \mathrm{~m}$ monthly PRISM dataset.

(Ceccarelli and Grando, 1996), and can produce grain with only 330-350 mm of annual rainfall (Oelke et al., 1990; Lyon et al., 2008a). As a warm season crop, proso millet is sensitive to frost and requires warm temperatures for germination and development. Optimal soil temperatures for seed germination range from 20 to $30^{\circ} \mathrm{C}$ (Baltensperger et al., 1995a; McDonald and Copeland, 1997; Amadou et al., 2013). As a $\mathrm{C}_{4}$ crop with a low transpiration ratio, proso millet can efficiently fix carbon under conditions of drought, high temperatures, and limited nitrogen and $\mathrm{CO}_{2}$. Proso millet avoids drought sensitivity by reaching maturity rapidly (Baltensperger et al., 1995a). In addition, at temperatures above $30^{\circ} \mathrm{C}$, proso millet stops vegetative growth, ceases to flower, and maintains its primary stem at a shorter height to better resist drought conditions (Herdrich, 2001; Sateesh, 2010; Changmei and Dorothy, 2014) (Figure 2).

Proso millet can be grown on sandy loam, slightly acidic, saline, and low-fertility soils (Riley et al., 1989; Changmei and Dorothy, 2014). However, this crop grows poorly on waterlogged soils (Seghatoleslami et al., 2008; Hunt et al., 2011) and on coarse, sandy soils (Hardman, 1990; Williams et al., 2007). Proso millet thrives in low $\mathrm{pH}$ soils and most of its seeds germinate well on soils with $\mathrm{pH}$ of 5.5 to 6.5 (Baltensperger et al., 1995a; Lyon et al., 2008b). However, plants grown on soils with $\mathrm{pH}$ above 7.8 show symptoms of iron chlorosis. The Palouse region of Washington State in the U.S. has predominantly acidic soils with pH $\leq 5$ (Koenig et al., 2011; McFarland et al., 2015), which could seriously constrain millet cultivation.

\section{CURRENT AND POTENTIAL PRODUCTION OF PROSO MILLET IN THE U.S.}

Economically important species of Paniceae (the largest tribe of the Poaceae (Gramineae) grown in the U.S. include proso millet, foxtail millet, and pearl millet (Baltensperger, 2002). Proso millet was first introduced to the U.S. in 1875 by GermanRussian immigrants who planted the crop along the eastern Atlantic Coast. Currently, the total cultivated area of proso millet in the U.S. is approximately 204,366 ha (USDA-NASS, 2016). Most of this production is in the semi-arid regions of the Great Plains, where approximately 184,131 ha per year are planted (McDonald and Copeland, 1997; Rajput et al., 2014; USDANASS, 2016). The Great Plains region is an area of widespread dryland crop production, with wheat being the dominant crop. Proso millet is among the preferred crops for planting after wheat in the Central Great Plains because it helps control weeds and conserve stored moisture (Anderson, 1990; Lyon et al., 2008b; Krishna, 2013). In 2015, the Central Great Plains states of Colorado, Nebraska, and South Dakota were the major producers of U.S. proso millet, with 109,265 ha, 42,492 ha, and 28,328 ha, respectively (USDA-NASS, 2016). Other states producing significant quantities of proso millet include Kansas, Wyoming, Minnesota, and North Dakota (McDonald et al., 2003).

In the U.S., most of the proso millet crop is utilized for birdfeed and in cattle-fattening rations (McDonald et al., 2003; AGMRC, 2012 ${ }^{1}$ ). However, millet has high nutritional content and is a major source of energy and protein for African and Asian countries (Rachie, 1975; Amadou et al., 2013). Efforts to develop higher yielding and better adapted cultivars could increase the importance of proso millet in the U.S. food and feed industry (Baltensperger et al., 1995a; Berglund, 2007). Among the millet species produced worldwide, proso millet is the most important species traded in the world market, and the U.S. is among the top producers (Castro, 2013). The U.S. generally exports $15-20 \%$ of its annual millet production to over 70 countries, primarily as feed. The largest export markets for U.S. proso millet include the Netherlands, the United Kingdom, Canada, and Japan (Powell et al., undated ${ }^{2}$; USDA FAS, 2012). Argentina is a major competitor in this export market (Powell et al., undated) ${ }^{2}$.

\section{PROSO MILLET PRODUCTION IN THE PACIFIC NORTHWEST}

Historically, millets and other warm season crops such as sudan grass and sorghum were grown as forage and grain feed for livestock and birds in different regions of Oregon (Schoth and Rampton, 1939). In many regions of the PNW, these crops were also grown as temporary or emergency crops in locations or during seasons unfavorable for other, more profitable crops. However, challenges in the marketplace caused a decline in acreage planted to these crops, especially proso millet. Since market opportunities were limited, growers needed to arrange for buyers before planting (Schoth and Rampton, 1939). Moreover, proso millet is associated with birdfeed; hence, concerted marketing is required to change consumers' perception. Only recently has proso millet been promoted as a

\footnotetext{
${ }^{1} \mathrm{http}$ ///www.agmrc.org/commodities-products/grains-oilseeds/proso-millet/

${ }^{2}$ http://www.rma.usda.gov/pilots/feasible/pdf/millet.pdf
} 
whole grain alternative in a healthy diet. Currently, Shepherd's Grain Cooperative is working with farmers in Idaho and Washington to grow proso millet and other warm season crops, including sunflower, teff, amaranth, and sorghum. From 2014 to 2016, based on interviews conducted during the Shepherd's Grain field days, growers expressed satisfaction about the inclusion of proso millet in their crop rotations (Jeremy Bunch and Eric Odberg, personal communication).

According to Herdrich (2001), of all the millets, proso millet would perform best in the PNW, largely because it can be grown as a dryland crop, without supplemental irrigation. Almost all proso millet produced in the U.S. is grown under conventional dryland/rainfed conditions in Colorado, Nebraska, and South Dakota (Schaible and Aillery, 2012). Only a small area in these states is irrigated (McDonald et al., 2003). Of the approximate 4,046 irrigated hectares of proso millet in the U.S., about one-half are located in Nebraska (Schaible and Aillery, 2012). Proso millet is only irrigated for specific reasons, such as when it is planted as a replacement for irrigated wheat lost due to late hail damage. Nebraska has been the second highest producer of proso millet in the U.S.; in 2012, proso millet production contributed \$13 million to the state's economy (Santra, 2013).

Growers in the PNW could also benefit from proso millet's ability to produce grain under limited water conditions on marginal soils, with minimal agronomic inputs (Oelke et al., 1990; Santra, 2013). Although proso millet can be grown on various soil types and climate conditions, it thrives on well-drained loamy soils (Baltensperger, 2002). This soil type is predominant throughout the Columbia Plateau and across the intermediate precipitation zone of the inland dryland areas, including eastern and central Washington, eastern and north-central Oregon, the Idaho panhandle, and the intermountain region of southern Idaho (Schillinger et al., 2003; Williams et al., 2014). Another benefit of growing proso millet is that it can be grown as a catch crop when other crops fail or planting is delayed due to unfavorable weather (Hardman, 1990; Oelke et al., 1990; Herdrich, 2001; Adekunle et al., 2016).

\section{CROP ROTATION}

The planting time of proso millet fits well in rotation with winter annual crops such as winter wheat or warm-season broadleaf crops such as sunflower (Herdrich, 2001). Successful proso millet production in Nebraska is attributed to the practice of ecofallow-planting proso millet in standing wheat stubble in the spring to control weeds and to conserve stored soil moisture (Anderson, 1990). Potential problems for millet production in the PNW include competition from grassy weeds, summer annual broadleaf weeds, and perennial broadleaf weeds (Herdrich, 2001). Baltensperger et al. (1995a) found that planting millet after sunflowers provides more options for broadleaf weed control. Because proso millet has a shallow root system, it is often planted after sunflowers that have deep, extensive root systems and often deplete soil water at 6 feet or deeper. This deep depletion of soil water restricts the option of planting another deep-rooted crop after sunflowers, unless summer fallow is used to help restore soil water (Lyon et al., 2008b). A winter wheat/sunflower/proso millet/fallow rotation has been successful for some growers in the western Great Plains (Baltensperger et al., 1995a).

Proso millet can also be used in rotation with corn or sorghum because it tolerates atrazine, a primary chemical input in corn and sorghum production systems. The warmer soil temperatures in corn or sorghum stubble fields toward the end of spring due to high plant biomass, allow proso millet to be planted earlier (Lyon et al., 2008b). The density of the summer annual weed seedbank can decline by nearly $90 \%$ if the proso millet crop is followed by two winter crops or by a winter crop and fallow period (Anderson et al., 1999). An earlier study found that grain yield of proso millet increased $23 \%$ when fall weeds were reduced by sweep plowing after wheat harvest (Anderson et al., 1986). More recent studies have found that adding proso millet into a winter wheat/fallow rotation can extend and diversify this crop rotation system to provide multiple benefits. These benefits include helping to: (1) control winter annual grass weeds, (2) manage disease and insect pressure, and (3) preserve deep soil moisture for wheat (Lyon et al., 2008b; Santra, 2013).

In low-rainfall environments of the PNW, the traditional, 2year winter wheat/summer fallow rotation is the most economical production system. This crop rotation is commonly employed in regions such as the Columbia Plateau that receives less than $330 \mathrm{~mm}$ of annual rainfall, though it is considered inadequate to produce crops every year (Rasmussen et al., 1994, 1998). In the Columbia Plateau, the winter wheat/summer fallow rotation is employed by growers to store winter precipitation and control weeds (Rasmussen et al., 1998). In contrast, in areas which receive higher annual rainfall $(375-550 \mathrm{~mm})$, growers use 2- to 5 -year rotation systems that include winter wheat-spring barley or spring wheat/summer fallow (Rasmussen et al., 1998; McCool and Roe, 2005).

Annual cropping in the PNW is limited by low rainfall and soil moisture. According to Rasmussen et al. (1998) and Williams et al. (2014), annual cropping that includes alternative crops and spring planting has better weed and disease management compared to summer fallow. In addition, Rasmussen et al. (1998) recommended using an annual cropping system to maintain soil organic matter. In their study, Rasmussen et al. (1998) found that any cropping system with summer fallow lost soil organic matter due to high biological oxidation and absence of $\mathrm{C}$ inputs during the fallow year. Warm season crops such proso millet could replace summer fallow in winter wheat-fallow rotations. Growing crops such as proso millet instead of summer fallow would provide more surface cover and help growers meet conservation practice requirements. As an added benefit, proso millet can be an extra cash crop in a wheat-proso-fallow rotation. Furthermore, proso millet can be a catch crop to compensate for wheat crop loss due to freezing, wind erosion, drought, or hail (Baltensperger, 1996).

Proso millet is one of the most efficient crops for removing water from the topsoil and converting it to dry matter, because its root depth is generally limited to the upper $92 \mathrm{~cm}$ of soil. Additional summer moisture is beneficial, as it can replenish the low water reservoir in the subsoil for proso millet's use (Baltensperger et al., 1995a). However, growers in some regions 


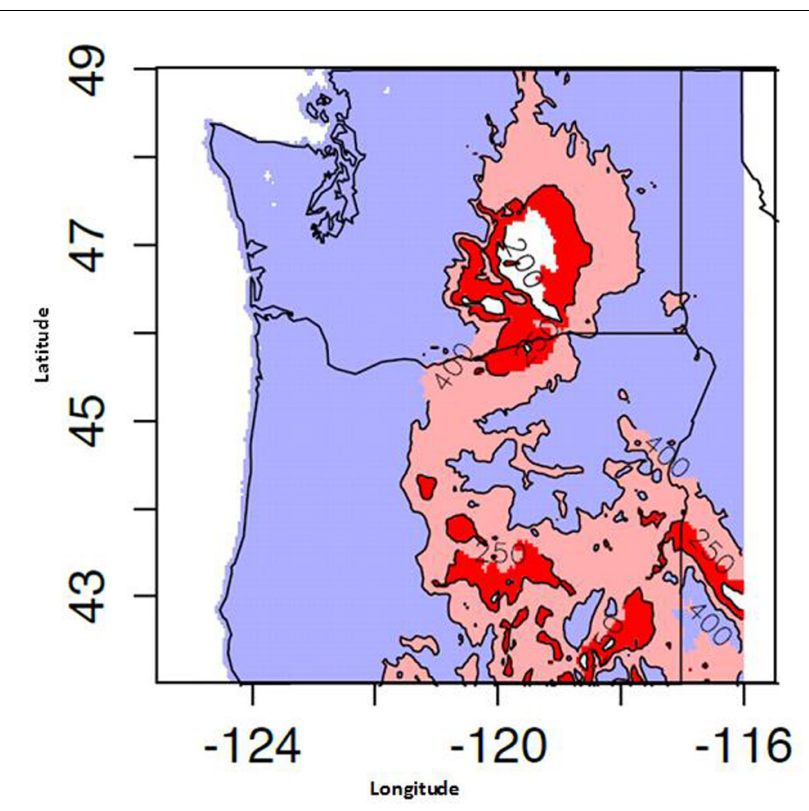

FIGURE 3 | Mean May-September precipitation availability for the years 1981-2014. Computed using $800 \mathrm{~m}$ monthly PRISM dataset.

of PNW are not guaranteed additional summer moisture due to the region's typical weather patterns. The PNW has hot, dry summers, and most rainfall comes during the winter months, with average annual precipitation below $330 \mathrm{~mm}$ (Figure 3). This weather pattern includes areas east of the Cascade Mountains where average annual rainfall is much less than $330 \mathrm{~mm}$. Some farming regions in this environment receive as little as $180 \mathrm{~mm}(\mathrm{CIG})^{3}$. The Palouse region of Washington only receives, on average, approximately $60 \mathrm{~mm}$ of summer precipitation (WeatherDB ${ }^{4}$ ). This low summer moisture might pose a challenge to growing proso millet in the PNW, especially if precipitation does not occur when most needed. The first 2 weeks are critical when growing proso millet. For example, lack of rain during the first 2 weeks after planting can cause a poor stand and subsequent yield loss (Baltensperger et al., 1995a). On the other hand, if sufficient rainfall occurs later in the season, proso millet can still produce a reasonable yield despite a long, early period of limited rainfall (McDonald et al., 2003).

In Nebraska, the grain yields of proso millet respond more consistently to soil water at planting than do other longduration crops such as corn, grain sorghum, or sunflower (Baltensperger et al., 1995a; Lyon et al., 2008b). This finding suggests that soil water levels at planting may be a reliable predictor of grain yields (Baltensperger et al., 1995a). In a study comparing conventional tillage, reduced tillage, and no-tillage production systems, results indicated that wheat-corn-proso millet and wheat-millet rotations produced almost double the total grain yield compared to a wheat-fallow rotation (Anderson et al., 1999). Continuous cropping with a wheat-corn-proso

${ }^{3}$ http://cses.washington.edu/cig/pnwc/pnwc.shtm

${ }^{4}$ http://rainfall.weatherdb.com/1/19858/PaloUSe-Washington millet rotation using no-till management would increase the soil concentration of glomalin, which is an important molecule in aggregate stabilization (Wright and Anderson, 2000). Anderson et al. (1999) and Nielsen et al. (2005) stated that producers could grow crops more frequently if crop residues are maintained on the soils through reduced tillage or no-till. Soil-water relations change under no-till systems, with higher water content in the 0$15 \mathrm{~cm}$ soil layer and less evaporation from the soil surface due to the presence of continuous crop residues (Anderson, 1990).

Often, growers who wish to avoid summer fallow plant proso millet as a transition crop when rotating back to winter wheat from a full-season summer crop (Baltensperger et al., 1995a). Since proso millet has a shallow root system, the top $92 \mathrm{~cm}$ of the soil profile is quite dry after harvest, but the deeper soil water has been preserved for use by winter wheat plants in the spring (Baltensperger et al., 1995a; McDonald et al., 2003). Moreover, winter wheat sown into proso millet stubble under no-till systems are less prone to damage from blowing soil compared to those planted into summer fallow. Increasing soil residue levels may also improve snow capture, providing much needed moisture for the crop (Anderson, 1990; Baltensperger et al., 1995a).

\section{NUTRITIONAL AND HEALTH BENEFITS OF PROSO MILLET}

Millets are a major source of energy and protein and have high nutritive value, comparable to major cereals such as wheat, rice, and maize (Amadou et al., 2013; Saleh et al., 2013) (Table 2). Millets are unique among the cereals because of their high calcium, iron, potassium, magnesium, phosphorous, zinc, dietary fiber, polyphenols, and protein content (Hulse et al., 1980; Devi et al., 2014; Gupta et al., 2014). Millets are gluten-free, ideal for people who are gluten-intolerant, though millet flour cannot be used for raised bread (Hulse et al., 1980; Thompson, 2009; Amadou et al., 2013; Santra, 2013). Millets are easy to digest. They contain a high amount of lecithin, which provides excellent support for nervous system health by helping to restore nerve cell function, regenerate myelin fiber, and intensify brain cell metabolism. Millets are also rich in micronutrients such as niacin, B-complex vitamins, Vitamin B6, and folic acid (Hulse et al., 1980; Pathak, 2013). Millets generally contain significant amounts of essential amino acids, particularly those containing sulfur (methionine and cysteine). Saleh et al. (2013) reported that millets are good sources of essential amino acids, except lysine and threonine, but are relatively high in methionine. Millets also have higher fat content than maize, rice, and sorghum (Obilana and Manyasa, 2002).

Ravindran (1991) reported the composition of the various millets, including the four varieties of foxtail millet (Setaria italica). The average protein contents of common millet, finger millet and foxtail millet were 14.4, 9.8 and 15.9\%, respectively. The crude fiber content of the millets ranged from 3.2 to $4.7 \%$. In general, the mineral contents were high compared with those of other common cereal grains. Considerable between- and withinmillet differences were observed with regard to most nutrients analyzed. The overall results are suggestive of the underexplored 
TABLE 2 | Nutritional composition of proso millet (Panicum miliaceum L.) compared to other small millets, wheat and rice (100 g).

\begin{tabular}{|c|c|c|c|c|c|c|c|c|}
\hline Crop & Protein (g) & $\begin{array}{l}\text { Carbohydate } \\
\text { (g) }\end{array}$ & Fat (g) & $\begin{array}{l}\text { Dietary } \\
\text { fiber }(g)\end{array}$ & $\begin{array}{l}\text { Mineral } \\
\text { matter }(g)\end{array}$ & $\begin{array}{l}\text { Calcium } \\
\text { (g) }\end{array}$ & $\begin{array}{l}\text { Phosphorus } \\
\text { (mg) }\end{array}$ & $\mathrm{Fe}(\mathrm{mg})$ \\
\hline $\begin{array}{l}\text { Proso millet } \\
\text { (Panicum miliaceum L.) }\end{array}$ & $12.5^{*}$ & 70.4 & 3.1 & 14.2 & 1.9 & 14 & 206 & 10.0 \\
\hline $\begin{array}{l}\text { Finger millet } \\
\text { Eleusine coracana (L.) Gaertn. }\end{array}$ & 7.3 & 72.0 & 1.3 & $18.8^{*}$ & 2.7 & $344^{*}$ & 283 & 3.9 \\
\hline $\begin{array}{l}\text { Kodo millet } \\
\text { Paspalum scrobiculatum L. }\end{array}$ & 8.3 & 65.0 & 1.4 & 15.0 & 2.6 & 27 & 188 & 12.0 \\
\hline $\begin{array}{l}\text { Foxtail millet } \\
\text { Setaria italica (L.) P. Beauv. }\end{array}$ & 12.3 & 60.9 & 4.3 & 14.0 & 3.3 & 31 & 290 & 5.0 \\
\hline $\begin{array}{l}\text { Little millet } \\
\text { Panicum sumatrense } \\
\text { Roth ex Roem. and Schult. }\end{array}$ & 7.7 & 67.0 & 4.7 & 12.2 & 1.5 & 17 & 220 & 6.0 \\
\hline $\begin{array}{l}\text { Barnyard millet } \\
\text { Echinochloa esculenta (A. Braun) H. Scholz }\end{array}$ & 6.2 & 65.5 & 2.2 & 13.7 & $4.4^{*}$ & 11 & 280 & $15.0^{*}$ \\
\hline $\begin{array}{l}\text { Wheat } \\
\text { Triticum aestivum L. }\end{array}$ & 11.8 & 71.2 & 1.5 & 12.9 & 1.5 & 41 & 306 & 3.5 \\
\hline $\begin{array}{l}\text { Rice } \\
\text { Oryza sativa L. }\end{array}$ & 6.8 & 78.2 & 0.5 & 5.2 & 0.6 & 45 & 160 & 1.8 \\
\hline
\end{tabular}

*Higher than major cereals and wheat, adapted from Saha et al. (2016).

potential of millets as sources of dietary nutrients. The protein content in proso millet is around $11 \%$ (dry basis) (Kalinova and Moudry, 2006). They reported that the proso millet protein is richer in essential amino acids (leucine, isoleucine, methionine), compared to wheat. Hence, the protein quality of proso (Essential Amino Acid Index) was higher (51\%) compared to wheat. Lorenz and Dilsaver (1980) conducted a thorough study on the milling characteristics and proximate composition and nutritive value of the proso-millet flours. Compared with wheat, millet flours were high in ash and crude fat and were higher in protein content.

Millet has many nutritional and medical functions (Obilana and Manyasa, 2002; Yang et al., 2012). Millets are rich in health-promoting phytochemicals and considered functional foods (Pathak, 2013). Consumption of proso millet and other millets is associated with reduced risk of type- 2 diabetes mellitus because whole grains like millet are a rich source of magnesium. Magnesium acts as a co-factor in a number of enzymatic reactions that regulate the secretion of glucose and insulin. Magnesium can also reduce the frequency of migraine headaches and heart attacks, and is beneficial for people suffering from atherosclerosis and diabetic heart disease (Shobana and Malleshi, 2007; Gélinas et al., 2008). Millet is a good source of phosphorus, which plays a vital role in maintaining cell structure in the human body (Kumari and Sumathi, 2002). Phosphorus in millet helps in the formation of the mineral matrix of the bone and is an essential component of ATP, which is the energy currency of the body (Kumari and Sumathi, 2002; Liang et al., 2010; Devi et al., 2014). A single cup of cooked millet provides around $24 \%$ of the body's daily phosphorus requirement. Furthermore, phosphorus is a very important constituent of nucleic acids, which are the building blocks of the genetic code (Kumari and Sumathi, 2002).

Since millets are high in fiber, antioxidants, and complex carbohydrates, they can be valuable in preventing CVD and cancer. Coulibaly et al. (2011) stated that millet is an important crop with a wide range of health benefits due to the phytochemicals in millet grains. Zhang et al. (2014) studied the phytochemical content, antioxidant activity, and antiproliferative properties of three diverse varieties of proso millet. Anti-proliferative activities were also studied in vitro against MDA human breast cancer and $\mathrm{HepG}_{2}$ human liver cancer cells. Results showed a differential and possible selective antiproliferative property of the proso millet. Consuming millets can lower cholesterol and phytate, which are associated with CVD and cancer risk. Lignans, essential phytonutrients present in millet, act against different types of hormone-dependent cancers, such as breast cancer, and help reduce the risk of heart disease (Coulibaly et al., 2011). Regular consumption of millet can reduce high blood pressure and high cholesterol levels in postmenopausal women suffering from signs of CVD (Shahidi and Chandrasekara, 2013). Millets can also slow down the aging process in humans (Pathak, 2013; Shahidi and Chandrasekara, 2013) and may protect against age-onset degenerative diseases (Pathak, 2013).

Millet protein has a beneficial influence on metabolism of cholesterol (Nishizawa and Fudamo, 1995). Nishizawa et al. (2002) examined the effects of dietary proso-millet protein on plasma levels of high-density lipoprotein (HDL) cholesterol in different rats from animals reported in our previous studies. They reported that the ingestion of the millet protein elevates plasma levels of HDL-cholesterol like our earlier works. Taking into account the anti-atherogenic function of HDL, therefore, the millet protein would be useful as a new food ingredient, which has the function that regulates cholesterol metabolism. This protein is also considered beneficial in the prevention of liver injury (Nishizawa et al., 2002).

Millet can be cooked and prepared in different ways. The grains can be boiled, steamed to make salad, or fully cooked similar to rice. Together with other ingredients, millet flour can be made into porridge (Santra, 2013). Because of its mild flavor, light color, gluten-free quality, and potential health benefits, 
proso millet has been receiving growing interest from the food industries in Europe and North America (Santra, 2013). Organic proso millet has a niche market because of its nutritional properties (UNL NebGuide Alternative uses of Proso Millet, G2218) ${ }^{5}$. In addition, the market for gluten-free food in the U.S. bread and grain industry is growing. This market grew $17 \%$ in 2012 and is projected to be worth $\$ 6.6$ billion by 2017 (CDA, $\left.2016^{6}\right)$. Furthermore, proso millet can be a substrate in distilled liquors and beers and is used to make fermented beverages in Africa and Asia. Thus, proso millet may also gain traction in the U.S. and European alcohol markets, especially in the gluten-free sector (Santra et al., 2015).

There is scarce information about millet integration and adoption into the food industry (Saleh et al., 2013). According to the Common Fund for Commodities (CFC) and International Crops Research Institute for Semi-Arid Tropics (ICRISAT) (CFC and ICRISAT, 2004), the industrial application of millets in developing countries is facing increasing competition from other industrially produced grain crops. Even though there are some studies reported in the literature about the nutritional composition, health benefits and uses of proso millet, there is still a broad gap in the literature specifically on the nutritional composition of different varieties and its applications in different food products. Studies on the processing methods to make diverse food products from proso millet are necessary. Information generated from these studies should be available to stakeholders in the food processing industry so that proso millet can be included as an ingredient in food products. More research is required to breed millet cultivars suited to different agroecosystems and to formulate best production practices. There is a need to correlate the agronomic characteristics with the nutritional properties and end-uses of proso millet. Efforts to educate people about the potential value of millets, including nutritional properties and health benefits, would help create market demand (Amadou et al., 2013; Saleh et al., 2013). In addition, conducting market research on proso millet and promoting it as an alternative whole grain in a healthy diet are essential for acceptance and consumption in developed countries (Amadou et al., 2013).

\section{GENETICS AND GENOMICS OF PROSO MILLET}

Proso millet is considered a minor crop compared to wheat, barley and potatoes, and this status is reflected not only in the amount of land cultivated but also in the extent of research in its genetics, genomics and breeding (Rajput and Santra, 2016). Kubešová et al. (2010) estimated the haploid genome size of P. miliaceum to be $1.04 \mathrm{pg}$ or $1017.2 \mathrm{Mb}$ (1C value). The use of molecular markers, generation of sequence information, creation of mapping populations and mutants, and construction of genetic maps, are prerequisites for genetic studies and molecular plant breeding in any crop (Varshney et al., 2010; Lata, 2015). At

${ }^{5} \mathrm{http}: / /$ extensionpublications.unl.edu/assets/pdf/g2218.pdf

${ }^{6} \mathrm{https} / / /$ www.colorado.gov/pacific/agmarkets/millet present, the genomic resources available for $P$. miliaceum are several types of molecular markers such as simple sequence repeat (SSR) and single nucleotide polymorphism (SNP) markers, expressed sequence tags (ESTs), sequences of the Waxy gene, miRNAS, gene-based markers, a genetic linkage map, and an assembled and characterized transcriptome (Table 3 ).

\section{Genetic Diversity Studies Using SSR Markers}

Conservation and increased use of proso millet germplasm, especially for breeding new cultivars, requires information on its genetic diversity (Hu et al., 2008; Dvořáková et al., 2015). Genebanks worldwide hold a rich collection of proso millet accessions, especially in areas where proso millet is still grown. There are 24,014 proso accessions held in 10 institutions based in China, Russia, India and the U.S. (Table 4). Moreover, farmers grow and preserve landraces of proso millet, often in remote areas of the world, thus maintaining its agricultural and functional diversity. These landraces have helped agrarian communities survive for generations in marginal lands (Newmaster et al., 2013). Scientists have examined the genetic diversity of proso millet accessions to investigate the genetic relationships among landraces, breeding lines and cultivars, construct phylogenetic trees and draw connections between genetic diversity and geographical origins. Several types of molecular markers have been used to estimate genetic diversity and relatedness in $P$. miliaceum accessions, including amplified fragment length polymorphism (AFLP) (Karam et al., 2004, 2006), random amplified polymorphic DNA (RAPD) (M'Ribu and Hilu, 1994; Colosi and Schaal, 1997), cleaved amplified polymorphic DNA (CAP) (Lágler et al., 2005), inter simple sequence repeats (ISSR) (Lágler et al., 2005; Trivedi et al., 2015), sequence related amplified polymorphism (SRAP) (Trivedi et al., 2015) and simple sequence repeat (SSR) polymorphic markers (Hu et al., 2009; Cho et al., 2010; Hunt et al., 2010, 2011; Rajput et al., 2014; Dvořáková et al., 2015; Rajput and Santra, 2016). More genetic diversity studies using SSR markers have been conducted compared to other PCR-based markers because SSR markers are (1) neutral, abundant, and evenly distributed in the genome; (2) more informative since they are co-dominant, multi-allelic, and have high polymorphic information (PIC); and (3) easier to reproduce and score (Rajput et al., 2014).

Since there are limited genomic resources for proso millet, SSR markers have been derived from available sequence data of other plant species (Hu et al., 2009; Rajput et al., 2014; Rajput and Santra, 2016). Hu et al. (2009) used 46 SSR markers from rice, wheat, oat and barley to examine the genetic diversity of 118 Chinese accessions with different ecotypes. The genetic similarity (GS) coefficients among the accessions were moderate to high and $\mathrm{Hu}$ et al. (2009) grouped the accessions into five clusters which closely corresponded with the ecological areas of the collection sites. The clustering of accessions was also consistent with the GS matrix. Rajput et al. (2014) used comparative genomics to develop SSR markers from sequences of switchgrass (Panicum virgatum L.). Since switchgrass is taxonomically the closest species to proso millet, $62 \%$ of the markers they tested on eight genotypes were amplified. Of these, 254 were highly 
TABLE 3 | List of molecular markers reported in proso millet (Panicum miliaceum L.).

\begin{tabular}{|c|c|c|}
\hline DNA markers & Number of markers & Reference \\
\hline Random amplified polymorphic DNA (RAPD) & Five & Colosi and Schaal, 1997 \\
\hline Amplified fragment length polymorphism (AFLP) & $\begin{array}{l}\text { Eight primer pairs which amplified a total of } 450 \text { fragments, } 339 \text { of which } \\
\text { were polymorphic }\end{array}$ & Karam et al., 2004, 2006 \\
\hline \multirow[t]{2}{*}{ Inter simple sequence repeats (ISSR) } & Seven & Lágler et al., 2005 \\
\hline & Eight & Trivedi et al., 2015 \\
\hline Polymerase chain reaction (PCR)-based markers & Six primer pairs for the intron splice junction (ISJ) & Hu et al., 2008 \\
\hline Primers from $5 \mathrm{~S}$ rDNA repeats & Two types of repeats different in the length of the NTS region & Pak et al., 2012 \\
\hline microRNAs (miRNAs) & 43 potential miRNAs which may regulate 68 target genes & Wu et al., 2012 \\
\hline Sequence related amplified polymorphism (SRAP) & 40 & Trivedi et al., 2015 \\
\hline \multirow[t]{6}{*}{ Simple sequence repeat (SSR) } & $\begin{array}{l}46 \text { markers from other plant species ( } 21 \text { from rice; } 15 \text { from wheat; } 9 \text { from } \\
\text { oat; } 1 \text { from barley) }\end{array}$ & Hu et al., 2009 \\
\hline & $\begin{array}{l}25 \text { markers from proso millet by constructing a SSR-enriched library from } \\
\text { genomic DNA }\end{array}$ & Cho et al., 2010 \\
\hline & $\begin{array}{l}348 \text { markers from switchgrass, of which } 254 \text { were highly polymorphic in } \\
\text { proso millet }\end{array}$ & Rajput et al., 2014 \\
\hline & 11 SSR markers developed from foxtail millet & $\begin{array}{l}\text { Kumari et al., 2013; Trivedi } \\
\text { et al., } 2015\end{array}$ \\
\hline & $\begin{array}{l}500 \text { primer pairs developed by high-throughput sequencing; } 67 \\
\text { polymorphic SSR primers used in study }\end{array}$ & Liu et al., 2016 \\
\hline & 35,000 loci discovered through transcriptome characterization & Yue et al., 2016a \\
\hline \multirow[t]{2}{*}{ Gene-specific primers } & $\begin{array}{l}\text { Three primer pairs based on sequences of the GBSSI (Waxy) gene reported } \\
\text { by Hunt et al., } 2010 \text { to distinguish waxy genotypes }\end{array}$ & Araki et al., 2012 \\
\hline & $\begin{array}{l}\text { Four Dof domain and } 20 \text { Dof genes specific primers; for the coding regions } \\
\text { of the Dof (DNA binding with One Finger) transcription factor }\end{array}$ & Kushwaha et al., 2015 \\
\hline Expressed sequence tags (ESTs) & 211 ESTs, all derived from drought stress induced leaf tissues & Saha et al., 2016 \\
\hline \multirow[t]{2}{*}{ Differentially expressed genes } & $\begin{array}{l}62,543 \text { unigenes functionally annotated from the de novo assembly and } \\
\text { characterization of the proso millet transcriptome }\end{array}$ & Yue et al., 2016a \\
\hline & 32 PmWRKY genes involved in abiotic-stress response & Yue et al., 2016b \\
\hline \multirow[t]{2}{*}{ Single sequence polymorphism (SNP) } & $\begin{array}{l}833 \text { SNP markers used to construct a genetic linkage map and conduct } \\
\text { QTL-linkage study }\end{array}$ & Rajput et al., 2016 \\
\hline & 406,000 SNP loci identified in the transcriptome of proso millet & Yue et al., 2016a \\
\hline
\end{tabular}

TABLE 4 | Germplasm collections of proso millet (Panicum miliaceum L.) and institute headquarters.

\begin{tabular}{|c|c|c|c|}
\hline Country & Number of & essions & Institution \\
\hline China & 6,517 & & Institute of Crop Germplasm Resources, Chinese Academy of Agricultural Science (ICGR-CAAS) \\
\hline Ukraine & 5,022 & 1,046 & National Centre for Plant Genetic Resources of Ukraine, Yuryev Plant Introduction Institute UAAS \\
\hline \multirow{2}{*}{ U.S. } & \multirow{2}{*}{1,432} & 719 & Plant Genetic Resources Conservation Unit, USDA-ARS, Griffin, GA, U.S. \\
\hline & & 713 & North Central Regional Plant Introduction Station, USDA-ARS, Ames, lowa, U.S. \\
\hline Poland & \multicolumn{2}{|l|}{721} & Botanical Garden of the Plant Breeding and Acclimatization Institute in Bydgoszcz \\
\hline Mexico & \multicolumn{2}{|l|}{400} & Estación de Iguala, Instituto Nacional de InvestigacionesAgricolas (INIA) \\
\hline Japan & \multicolumn{2}{|l|}{302} & National Institute of Agrobiological Sciences (NIAS) \\
\hline
\end{tabular}

Adapted from Dwivedi et al. (2012) and Goron and Raizada (2015).

polymorphic and generated 984 alleles. Interestingly, eight of these polymorphic markers correspond to highly conserved sequences in plants associated with drought and flood tolerance.

Cho et al. (2010) developed the first SSR markers for proso millet by constructing a SSR-enriched library from genomic DNA. They tested 25 markers on 50 accessions of P. miliaceum and detected 110 alleles. Hunt et al. (2011) used 16 of the markers developed by Cho et al. (2010) to examine the genetic diversity and phylogeography of 98 landrace accessions across Eurasia. In their study, they found strong geographic structuring where two genetic clusters had marked correspondence with two (eastern and western) geographic clusters. The eastern cluster was further divided into four sub-clusters or gene pools, while the western cluster into two sub-clusters. The eastern cluster included samples from China, Mongolia, Nepal and northeastern India, the Russian Far East, Korea and Japan; while the western 
cluster included samples from Ukraine, the Caucasus, European Russia, central Asia, northwestern India, Pakistan, and ten samples from China and Mongolia. In their study, Hunt et al. (2011) traced the molecular trail of proso millet through the Eurasian steppe region, a trail generated by genetic variation, evolutionary and population processes, linkage of SSR loci and genes coding for adaptive traits, and selection by humans for culinary traits. Using archeobotanical and molecular diversity data, Hunt et al. (2011) postulated various theories on the spread of proso millet from its centers of domestication.

Using a mix of SSR markers from other species and those developed on proso millet, Rajput and Santra (2016) screened 709 SSR markers on eight diverse genotypes, with the goal of examining the genetic diversity of proso millet germplasm in the U.S. Of these, 100 SSR markers were polymorphic, including 80 from switchgrass (Rajput et al., 2014), six from proso millet (Cho et al., 2010), and 14 from other species - rice (7), wheat (5), oat (2) (Hu et al., 2009). These polymorphic markers were then used on 90 proso millet genotypes representative of the whole USDAARS collection based in Ames, Iowa. The 90 genotypes could be considered a core collection since it consists of accessions from 25 countries, including 14 U.S. and one Canadian cultivar. Analysis of morphological and agronomic traits and molecular data revealed a wide range of genetic diversity in the core collection. However, all cultivars developed in the U.S. were grouped into one cluster. All 14 U.S. cultivars were developed through selection of landraces and conventional plant breeding but only six of these cultivars are still cultivated in the U.S. According to Rajput and Santra (2016), the genetic base of these six cultivars is narrow since only a few lines were used as parents. The work of Rajput and Santra (2016) are particularly relevant to the potential inclusion of diverse proso millet accessions in PNW crop rotations. Their results will also help future breeding programs for proso millet in the PNW, especially in the selection of parents for important traits such as tolerance to biotic and abiotic stresses.

Liu et al. (2016) used high-throughput sequencing to develop SSR markers specific to proso millet and thus increase the number of SSR markers researchers can use. They generated 500 primer pairs which they screened on eight accessions randomly selected from a pool of 73 Chinese accessions. Of these, 162 primer pairs produced polymorphic and reproducible fragments. From these primer pairs, 67 SSR markers were developed and used to examine the genetic diversity of 88 accessions consisting of landraces and cultivars. They detected 179 alleles and 349 genotypes, revealing a moderate level of genetic diversity. The 88 accessions were separated into four groups with a GS level of 0.633 by cluster analysis based on UPGMA. The clustering based on genetic diversity also corresponded to geographical regions, similar to the results obtained by M'Ribu and Hilu (1994), Hu et al. (2009), and Hunt et al. (2011). Cultivars were also grouped according to the geographical regions in which they were registered, with specific varieties and their parents often placed in the same group, also similar to the findings of M'Ribu and Hilu (1994), Hu et al. (2009), and Cho et al. (2010). These results suggest that breeding of proso millet in specific regions has proceeded in isolation (Liu et al., 2016). Similar to Trivedi et al. (2015), Liu et al. (2016) observed abundant morphological variation in the Chinese accessions, but more molecular markers or different types of markers are needed to assess their genetic diversity. These Chinese gene pools could also be valuable to future proso millet breeding programs since some accessions and ecotypes could be suitable to particular regions in the PNW.

\section{PCR-Based Molecular Markers for Genetic Diversity Analysis}

Instead of using markers developed from non-coding regions of the genome, primers from the coding region of genes or conserved domains can be used for genetic diversity analysis. $\mathrm{Hu}$ et al. (2008) used the polymerase chain reaction (PCR) to examine the genetic diversity of 32 proso millet accessions from China, together with six Indian accessions for comparison. They used primers designed for six intron splice junctions (ISJ) described previously (Weining and Langridge, 1991; Weining and Henry, 1995) together with long random primers to generate 56 DNA fragments, of which 42 (75\%) were polymorphic and reproducible. The clustering of accessions largely corresponded with the geographical locations of the origins of the accessions, similar to the results of M'Ribu and Hilu (1994), Hu et al. (2009), and Hunt et al. (2011). The PCR analysis used by Hu et al. (2008) also distinguished between landraces and cultivars. There was also a clear association of the glutinous trait (waxy)/nonglutinous trait (non-waxy) with genetic and geographical clusters.

Hunt et al. (2012) used the mutations in the Waxy gene to examine the phylogeny of Eurasian landraces, while Araki et al. (2012) developed markers based on these mutations to conduct the first phylogenetic study of Japanese landraces. The Waxy gene encodes glucose bound starch synthase (GBSS) in cereals, and the recessive allele $(w x)$ has loss of function of the enzyme. Since proso millet is a tetraploid, the Waxy gene has two loci, derived from its diploid ancestors. Hunt et al. (2010) sequenced the Waxy gene and reported that the gene has two homeologues, the L-form and the S-form, which have distinct gene sequences and intron lengths. The L-form has three alleles: one wildtype $\left(\mathrm{L}_{\mathrm{C}}\right)$ and two mutants resulting from sequence polymorphisms - an insertion of adenine residue causing a frame shift $\left(\mathrm{L}_{\mathrm{f}}\right)$ or substitution of cysteine with tyrosine $\left(\mathrm{L}_{Y}\right)$. On the other hand, the S-form has two alleles, the wildtype $\left(\mathrm{S}_{0}\right)$, and a mutant arising from a 15-bp deletion resulting to the loss of five amino acids $\left(S_{-15}\right)$. There are six possible combinations of these alleles, but only five combinations have been observed in the Eurasian landraces (Hunt et al., 2010). All the waxy accessions in their study had either of these two allele combinations, $\mathrm{S}_{-15} / \mathrm{L}_{\mathrm{Y}}$ or $\mathrm{S}_{-15} / \mathrm{L}_{\mathrm{f}}$. Examination of the spread of these alleles show distinct spatial distributions and correspond to the phylogeography of proso millet when examined with SSR markers (Hunt et al., 2012). Araki et al. (2012) developed PCR-based markers for the Waxy gene and used these markers to conduct the first phylogenetic study of Japanese landraces. They found that the genotype $S_{-15} / L_{Y}$ is prevalent among the waxy landraces in Japan. They also hypothesized that the non-waxy genotype $\left(\mathrm{S}_{0} / \mathrm{L}_{Y}\right)$ was introduced to Japan from northeast China, while the waxy genotype $S_{-15} / L_{Y}$ came from Korea. The northern part of East Asia, specifically the Primorskaya Province of Russia, could have also been the source 
of the other waxy genotype $S_{-15} / L_{f}$ as well as another pathway by which the non-waxy genotype came to Japan. These markers would be effective in genotyping proso millet accessions for the waxy/non-waxy trait in the U.S. core collection, and for other proso millet collections in the world.

Pak et al. (2012) designed primers from 5S ribosomal sequences to isolate the complete non-transcribed spacer (NTS) sequence to construct phylogenetic relationships of accessions from Korea, China, and Russia. Most of the genotypes from China and Russia clustered together, while the Korean genotypes clustered in another group. Kushwaha et al. (2015) used primers for the coding regions of the Dof (DNA binding with One Finger) transcription factor to compare the diversity of cereals and millets. The Dof transcription factors belong to a family of zinc-finger transcription factors widely distributed in the Plant Kingdom and involved in the regulation of biological processes exclusive to plants. Since there is a broad variation in the number of Dof genes in different crops, these can be employed for diversity analysis between genera and within a genus. Kushwaha et al. (2015) used four Dof domains and primers specific to 20 Dof genes. Analysis of the banding patterns generated by 35 sets of Dof domain and gene-specific primers separated the accessions into two major clusters. One cluster was composed of rice, sorghum, maize, finger millet, foxtail millet, barnyard millet and proso millet, while the other cluster was composed of wheat, barley, oat, little millet and kodo millet. Potentially, the DNA bands could be cloned and sequenced and give insight to the proso millet genome through comparative genomics (Kushwaha et al., 2015).

\section{miRNAS in Proso Millet}

Wu et al. (2012) have done preliminary work in characterizing proso millet microRNAs (miRNAs), which are non-coding RNAs important in post-transciptional regulation. Since there are limited proso millet genome sequences, $\mathrm{Wu}$ et al. (2012) used ESTs to predict miRNAs instead of using genomic survey sequence analysis as has been done in other crops. Wu et al. (2012) identified 43 potential miRNAs and their gene targets involved in biological processes such as development, metabolism and stress response. They selected 12 miRNAs to validate and eight were verified by Northern blot hybridizations. Their investigations in the role of miRNAs may help understand mechanisms for drought resistance used by proso millet, especially in the dryland farming systems of the PNW.

\section{SNP Markers, Genetic Linkage Map and Next-Generation Sequencing}

Rajput et al. (2016) constructed the first genetic linkage map of proso millet using SNP markers discovered through genotypeby-sequencing (GBS), an application of next-generation sequencing (NGS) protocols (He et al., 2014). Initially, 69,981 SNPs with a minor allele frequency of $>0.05$ were identified from raw DNA sequence reads. After four levels of filtering, 833 SNPs were eventually used to construct the linkage map which has 18 linkage groups. Since this is the first genetic map for proso millet, each linkage group was considered a chromosome as the haploid genome of proso millet has 18 chromosomes. Using these SNP markers, Rajput et al. (2016) mapped 18 quantitative trait loci (QTL) for eight traits, namely lodging, heading date, plant height, peduncle length, panicle length, grain shattering, 100 grain weight, and grains per panicle. These QTLs accounted for medium to high phenotypic variance (13-35\%). After confirmation and validation of these QTLs, the flanking SNP markers could be converted to PCR-based markers and employed in marker-assisted selection (MAS), especially for traits with high additive value such as lodging tolerance, grain shattering tolerance, and number of grains per panicle. The QTLs for these traits explain 22-35\% of the phenotypic variance.

\section{Transcriptome Analysis for Gene Discovery}

Using the Illumina high-throughput, paired-end RNA sequencing technology, Yue et al. (2016a) assembled and characterized de novo the proso millet transcriptome, the entire collection of RNA sequences in a cell. They used two cultivars for the study, 'Yumi 2' which is a waxy, drought-sensitive cultivar, and 'Yumi 3', a non-waxy, drought and salt tolerant cultivar. The quality of the raw reads were checked using SeqPrep and Sickle software, and then mixed and assembled using the Trinity program. Four databases were queried to predict the function of the unigenes, namely NCBI No-redundant protein database (NR), Swiss-Prot protein database (Swiss-Prot), Cluster of Orthologous Groups database (COG), and the Kyoto Encyclopedia of Genes and Genomes pathway database (KEGG). Three close relatives of proso millet, Panicum halli, Panicum virgatum, and Setaria italica, were used to predict the function of homologous genes of P. miliaceum. The MISA and SOAPsnp softwares were used to detect potential SSR and SNP markers, respectively. Yue et al. (2016a) identified differentially expressed genes (DEGs) between the two cultivars, and performed qRT-PCR analysis after the two cultivars were exposed to low temperature, heat and salt treatments.

RNA obtained from leaves, stem, root, shoots, flower and spike of the two cultivars were equally pooled and sequenced separately, then assembled. The assembly had high accuracy since Yue et al. (2016a) were able to map back to the contigs $93.80 \%$ of the reads belonging to 'Yumi 2', and 93.29\% to 'Yumi 3'. Of the 113,643 unigenes generated by the Trinity software, 60,352 unigenes were annotated in the NR, Swiss-Prot, COG, KEGG and Gene Ontology (GO) databases. Furthermore, 62,543 unigenes with homologs in the NR databases were annotated to major GO classes, namely cellular component (42.47\%), biological process $(38.93 \%)$, and molecular function (18.60\%). To classify their putative function, 33,671 unigenes were aligned to the KOG database and further classified into 25 different functional classes which could be grouped into the 'function prediction only class,' 'signal transduction mechanisms,' 'post-translation modification, protein turnover and chaperones,'transcription,' 'extracellular structures', and 'cell motility.' In addition, KEGG analysis was used to map 15,514 unigenes to 202 KEGG pathways, namely metabolic pathways, biosynthesis of secondary 
metabolites, biosynthesis of amino acids, pyrimidine metabolism, purine metabolism, peroxisome, spliceosome and plant-pathogen interaction.

Four differentially expressed genes (DEGs) which may be involved in abiotic stress response were selected for qRT-PCR analysis and their expression profiles examined further under different stress treatments. The Unigene 34608 is predicted to encode heat-shock factor-binding protein (HSBP1) which can affect HSF1 DNA binding activity and can also negatively regulate response to heat stress. The transcript levels of Unigene 34608 in 'Yumi 2' had small changes in expression levels under cold stress, reduced expression level by 0.26 -fold under heat stress, and 0.16-fold under salt stress compared to control plants. In contrast, the expression level of Unigene 34608 in 'Yumi 3' was temporarily elevated under cold and heat stress, even increasing 400-fold under cold stress for $6 \mathrm{~h}$ compared to control plants. Its expression declined under salt stress for $24 \mathrm{~h}$. Using the same analysis, the Unigene 41558 is postulated to encode a CBL-interacting protein kinase 9 (CIPK9) which interacts with calcium sensor and could play a role in low- $\mathrm{K}^{+}$ stress. The Unigene 33484 could play a role in osmoregulation, while Unigene 35973 could encode a zinc-finger protein gene ISAP1, which was reported to be involved in regulating cold, dehydration and salt tolerance in transgenic tobacco (Yue et al., 2016a). Further analysis of the proso millet transcriptome using computational prediction identified $32 \mathrm{PmWRKY}$ genes involved in abiotic stress response. In plants, the WRKY genes are key transcription factors regulating various physiological processes, including plant growth, development, and stress response (Yue et al., 2016b). In addition to detecting differentially expressed genes, Yue et al. (2016a) also identified 35,000 SSR and 406,000 SNP loci which can be developed as molecular markers.

\section{Breeding Proso Millet for Resistance to Biotic and Abiotic Stress}

For the PNW, aside from integrating existing millet cultivars into crop rotation systems, there is also a need to breed for cultivars adapted to the region and resilient to biotic and abiotic stresses. Genetic improvement through plant breeding requires effective utilization of diverse germplasm (Kole et al., 2015; Saha et al., 2016), identification and evaluation of core and mini-core collections (Salini et al., 2010; Upadhyaya et al., 2010, 2011; Goron and Raizada, 2015) and accurate phenotyping systems (Lata, 2015). Some traits which can be selected for under PNW growing conditions may include drought tolerance which can influence harvestindex, yield, and water use efficiency (Seghatoleslami et al., 2008); fermentation efficiency (Rose and Santra, 2013); and yield under abiotic and biotic stresses such as low input, salinity, drought, pests, and diseases (Goron and Raizada, 2015).

Cultivar development and genetic improvement of proso millet, as in other small millets, has been largely achieved through the direct selection of promising germplasm (Naylor et al., 2004). In the U.S., there are 15 cultivars of proso millet available to growers. Nine of these cultivars were selections from adapted landraces, and six were developed through hybridization followed by traditional breeding (Rajput et al., 2016). The variety 'Dawn' was the first of the modern proso varieties, and is the parent of most of the cultivars released in Nebraska (Lyon et al., 2008a). The white-seeded varieties 'Sunrise,' 'Huntsman,' and 'Earlybird' were developed from crosses, with the $\mathrm{F}_{1}$ and $\mathrm{F}_{2}$ seed increased in the greenhouse, and the $\mathrm{F}_{4}$ selections included in yield nurseries and regional trials (Baltensperger et al., 1995b,c, 1997). Prior to the elucidation of the molecular basis of the waxy endosperm trait by Hunt et al. (2010, 2012), and development of primer-based markers for the Waxy gene by Araki et al. (2012), the trait was investigated using segregation analysis of $\mathrm{F}_{3}$ populations. These $\mathrm{F}_{3}$ populations were derived from crosses between wild-type accessions such as 'Earlybird,' 'Sunrise' and 'Huntsman' and waxy accessions obtained from the USDA-ARS proso collection. It was postulated that a duplication of the inheritance factor of the recessive waxy trait occurred. The double mutant waxy lines resulted from the outcrossing of single null lines which arose from independent mutations in different backgrounds (Graybosch and Baltensperger, 2009). These double mutants were then selected and perpetuated in ancient Asia due to preference for glutinous texture. The first waxy proso millet cultivar released in the U.S. is 'Plateau,' with 'Huntsman' as the female parent and PI 436626 as the donor parent of the waxy trait (Santra et al., 2015).

Proso millet has few significant diseases in the Great Plains and Colorado, with head smut Sporisorium destruens (Schltdl.) Vanky = Sphacelotheca destruens (Schltdl.), bacterial stripe disease (Pseudomonas avenae), and kernel smut (Ustilago crameri) being the more important ones (McDonald et al., 2003; Lyon et al., 2008a) though there are no reports in the U.S. of molecular interventions to manage these diseases. In Ukraine, there have been efforts in breeding $P$. miliaceum for resistance to head smut and melanosis, which is blackening of the grain under the husk attributed to bacterial pathogens Pseudomonas syrinagae and Xanthomonas campestris pv. holcicola. Smut resistant varieties have been released in 1986 (Kh86) and 1989 (Kh22) by the Institute of Plant Production, Breeding and Genetics in Khar'kov, with some mutant lines having only 1.8 $8.3 \%$ infection under greenhouse conditions (Konstantinov et al., 1991). In China, Zhou et al. (2016) found moderate genetic diversity among 51 isolates of Sporisorium destruens using RAPD markers. The smut isolates also varied in virulence and were grouped into three pathotypes. These isolates were used to screen 280 accessions for resistance, and 10 accessions were found to be potential differential hosts for identification of pathotypes. The study of Zhou et al. (2016) laid the groundwork for breeding for head smut resistance of proso millet in China.

There are no serious insect pests for proso millet in the Great Plains, Colorado (McDonald et al., 2003; Lyon et al., 2008a) and elsewhere in the U.S. However, several insect pests still pose a constraint to proso millet production, and at present, resistant cultivars are developed through traditional breeding. The early proso cultivars released in the U.S. such as 'Huntsman,' 'Earlybird' and 'Sunrise' are resistant to the Russian wheat aphid [Diuraphis noxia (Mordvilko)] (Baltensperger et al., 1995b,c, 1997). In Oklahoma, Wilson and Burton (1980) screened proso 
millet cultivars for oviposition and feeding of five insect pests of grains, specifically cinch bugs [Blissus leucopterus leucopterus (Say)], corn earworms [Heliotis zea (Bodie)], fall armyworms [Spodoptera frugiperda (J.E. Smith)], southwestern corn borers [Diatraea grandiosella (Dyar)] and yellow sugarcane aphid [Sipha flava (Forbes)]. Corn earworms and armyworms deposited readily on proso but southwestern corn borers did not. Moreover, corn earworms larvae preferred the cultivar 'Dawn.' Meanwhile, 153 proso lines from the North Central Plant Introduction Station were evaluated for resistance to fall armyworm, with eight lines reported as resistant (Wilson and Courteau, 1984). On the other hand, weeds are managed using cultural practices such as crop rotations, tillage, row spacing and plant populations, and the use of pre-and post-emergence herbicides (McDonald et al., 2003; Lyon et al., 2008a).

Since most areas of the PNW fall under dryland farming systems, it is important to breed for drought and salinity tolerance in proso millet. Drought reduces the productivity of crops by limiting the water available for metabolic processes, but the level of reduction varies since drought interacts with factors such as genotype, developmental stage of the crop when drought occurs, as well as the duration and severity of the drought (Ngara and Ndimba, 2014). The effect of drought at the vegetative, ear emergence and seed filling stage on five proso millet genotypes was investigated by Seghatoleslami et al. (2008). Their results show that grain yield was reduced for all genotypes when drought occurred at the ear emergence stage, though two genotypes had higher harvest indices than the rest. Mid-season water stress was imposed on proso millet genotypes belonging to different maturity groups (early, middle, and late maturing) when 50\% of the plants were at the flowering stage. The water stress was continued for 10 consecutive days, followed by re-irrigation to field capacity until harvest (Emendack et al., 2011). Compared to Sorghum bicolor, P. miliaceum was more susceptible to water stress, with $77 \%$ reduction in yield, particularly with the middle and late-maturing types (Emendack et al., 2011). In another study, P. miliaceum had $36 \%$ yield reduction when water deficit was imposed both at pre- and post-heading stages, due to smaller number of grains per panicle, fewer panicles and reduction in total dry weight (Matsuura et al., 2012).

A primary abiotic stress, such as drought or salinity, can produce secondary stresses such as osmotic and oxidative stress (Wang et al., 2003). Drought and other abiotic stresses can cause early aging in plants, often observed as leaf senescence. In response, a series of defense reactions are initiated, physiological and biochemical reactions which can be used as indexes for drought resistance. Superoxide dismutase (SOD), catalase (CAT), and peroxidase (POD) are antioxidative enzymes involved in plant defense against drought (Zhang et al., 2012a). Karyudi and Fletcher (2002) found that of the 14 accessions of P. miliaceum tested, those with higher osmoregulative capacity had some degree of drought tolerance. Osmoregulative capacity was determined from the relationship between osmotic potential and leaf water potential on flag leaves of plants at heading stage. Jia et al. (2008) simulated drought stress conditions with PEG-6000 and investigated the biochemical characteristics of seedlings of two cultivars 'Yumi 1' and 'Yumi 3' under greenhouse conditions. They noted differences between the two cultivars, with the more susceptible cultivar 'Yumi 1' with increased electrolyte leakage, malondialdehyde content (MDA), praline and soluble surge content, while the there was reduced activity of the POD and SOD under 10-30\% PEG stress for 8 days. Using the same simulated drought conditions, Zhang et al. (2012b) subjected 10 proso millet cultivars to simulated water stress $(0.25 \mathrm{~g} / \mathrm{ml}$ PEG-6000) and found that SOD and POD activity and chlorophyll content can be used as effective indicators of drought resistance in proso millet during the seedling stage.

Leaf senescence and antioxidant enzymes in three cultivars of proso millet after anthesis were studied by Zhang et al. (2012a). The changes in chlorophyll content, antioxidant enzymes (SOD, CAT, POD), MAD and superoxide anion during seed filling to maturity were investigated with the primary goal of using these indices in the selection of drought resistant varieties. The cultivar 'Ningmi 13' had slower degradation ratio of chlorophyll content, higher activity of SOD and CAT, lesser POD, and smaller accumulation of MDA and superoxide anion, resulting to delayed leaf senescence and prolonged leaf functional period. Therefore, longer functional leaf period and higher SOD activities can be used as indices for selection of drought tolerant genotypes (Dai et al., 2011; Zhang et al., 2012b).

In plants, abiotic stress induces genes which encode proteins to protect plant cells, and genes which encode for proteins that regulate gene expression and signal transduction, such as transcription factors and protein kinases (Ngara and Ndimba, 2014). To investigate the genes induced by drought in P. miliaceum, Lin et al. (2006b) used a forward subtracted cDNA library constructed from normally watered leaves and leaves rehydrated after drought. They employed a suppressive subtraction hybridization technique to construct the cDNA library and 60 positive clones identified and sequenced. Of the 60 sequences, 32 EST were found highly homologous to known plant sequences expressed in response to abiotic or biotic stress. Furthermore, 28 ESTs are homologous to known proteins involved in signal transduction, transcription and protein processing. From this cDNA library, AFLP markers were generated by Lin et al. (2006a) to analyze genes differentially expressed in seedlings watered normally, those subjected to drought, and seedlings rehydrated after drought. Twelve fragments were amplified from the leaf samples under drought or rehydration regimes, then cloned and sequenced. Sequence analysis showed that one fragment was similar to UDP- $N$-acetylglucosamine- $N$-acetylmuramyl-(Pentapeptide), two fragments had significant homologous protein sequence with a rice retrotransposon, while two other fragments had significant homologous protein sequence with two hypothetical proteins (Lin et al., 2006a). Using the same cDNA library, Lin et al. (2008) amplified a full-length cDNA of $S$-adenosylmethionine synthase (SAMS) gene using PCR. The expression pattern of this gene was studied using semi-quantitative RT-PCR, and results show that its expression declined under drought, increased after rehydration, and then settled to normal levels $6 \mathrm{~h}$ after rehydration. It is postulated that this gene plays a key role in drought tolerance and water use efficiency (Lin et al., 2008). 


\section{Prospects for Future Genomic Research}

Molecular markers based on coding and non-coding regions of the proso millet genome were developed and used in genetic diversity analysis of landraces, breeding lines and cultivars. These molecular markers were also used on phylogenetic and phylogeographic studies to elucidate the genetic relationships of accessions and their geographical origins. In addition, molecular markers were used to trace the spread of proso millet from its center of domestication, and identify its wild progenitor. However, in relation to its abundant morphological variations, the genetic diversity of proso millet has not yet been adequately assessed (Trivedi et al., 2015; Liu et al., 2016). As in other millets, there are no mutants or mutant populations in proso millet to study gene functions through reverse genetics (Saha et al., 2016); the waxy mutants are natural variants of the waxy gene (Hunt et al., 2010). Previously, inadequate molecular markers combined with the challenges of a tetraploid genome such as inconsistent meiotic processes, allelic and non-allelic combinations, and poor correlation between genotype and phenotype (Saha et al., 2016) have made it difficult to conduct genetic and genomic studies in proso millet. However, with the discovery of SNPs by GBS (Rajput et al., 2016) and the identification of differentially expressed genes and thousands of SSR and SNP loci by transcriptome analysis (Yue et al., 2016a,b), a considerable number of molecular markers are currently available for genomic research in proso millet.

With the construction of the first genetic linkage map using SNPs and the first QTL mapping study conducted in proso millet (Rajput et al., 2016), there are now promising tools for molecular breeding of this crop (Varshney et al., 2010). With the discovery of thousands of unigenes, SSR and SNP loci by transcriptome analysis (Yue et al., 2016a,b), genetic linkage analysis, genome-wide association studies and genomic selection in proso millet are now distinct possibilities. Markerassisted selection can also be incorporated into proso millet breeding programs once the SNPs flanking QTLs have been confirmed and validated (Rajput et al., 2016). These molecular tools can be used to further study the rich genetic diversity of the proso millet accessions preserved in genebanks worldwide, in addition to the landraces grown and preserved by farmers which have helped agrarian communities survive for generations in marginal lands (Newmaster et al., 2013). These landraces

\section{REFERENCES}

Adekunle, A. A., Ellis-Jones, J., Ajibefun, I., Nyikal, R. A., Bangali, S., Fatunbi, A. O., et al. (2016). Agricultural Innovation in Sub-Saharan Africa: Experiences from Multiple Stakeholder Approaches. Accra: Forum for Agricultural Research in Africa (FARA).

Amadou, I., Gounga, M. E., and Le, G. W. (2013). Millets: nutritional composition, some health benefits and processing-A review. Emirates J. Food Agric. 25, 501-508. doi: 10.9755/ejfa.v25i7.12045

Anderson, R. L. (1990). No-till proso millet production. Agron. J. 82, 577-580. doi: 10.2134/agronj1990.00021962008200030028x

Anderson, R. L., Bowman, R. A., Nielsen, D. C., Vigil, M. F., Aiken, R. M., and Benjamin, J. G. (1999). Alternative crop rotations for the Central Great Plains. J. Prod. Agric. 12, 95-99. doi: 10.2134/jpa1999. 0095 will continue to be a rich source of unique alleles for breeding and genetic improvement of proso millet (Goron and Raizada, 2015).

\section{CONCLUSION}

Proso millet possesses many unique characteristics that make it a promising rotational crop for the PNW region of the U.S. Proso millet can utilize moisture more efficiently than wheat and long-season crops such as corn, grain sorghum, or sunflower because it has one of the lowest water requirements of any grain crop. Proso millet could help improve wheat productivity through its capacity to control winter annual grassy weeds, reduce insect and disease pressure, and preserve deep soil moisture for the subsequent wheat crop. In addition, proso millet can provide a rotational benefit to the dryland farming of the Palouse region of Washington, Oregon, and Idaho, where wheat is the keystone crop. Proso millet cultivation could promote diversification of wheat-based cropping systems and provide a regionally available source of a highly nutritious cereal grain.

\section{AUTHOR CONTRIBUTIONS}

$\mathrm{CH}$, JM, JDG, GG, and KM conceived and wrote the manuscript. MR, KK edited and provided additional information. All authors read and approved the final manuscript.

\section{ACKNOWLEDGMENTS}

We thank Washington State University Center for Transformational Learning and Leadership International Immersion for funding the research project that has generated this work. We also thank Washington State University Sustainable Seed Systems Lab (http://www. sustainableseedsystems.org/) for providing tools, guidance, and supervision for this work. Additionally, we thank Linda R. Klein for editing the final manuscript.

Anderson, R. L., Shanahan, J. F., and Greb, B. W. (1986). Effect of tillage systems on proso millet production. Agron. J. 78, 589-592. doi: 10.1371/journal.pone. 0089501

Araki, M., Numaoka, A., Kawase, M., and Fukunaga, K. (2012). Origin of waxy common millet, Panicum miliaceum L., in Japan. Genet. Res. Crop Evol. 59, 1303-1308. doi: 10.1007/s10722-011-9755-9

Baltensperger, D. D., Lyon, D. J., Anderson, R., Holman, T., Stymieste, C., Shanahan, J., et al. (1995a). EC95-137 Producing and Marketing Proso Millet in the High Plains. Lincoln, NE: University of Nebraska-Lincoln Extension, 709.

Baltensperger, D. D. (1996). "Foxtail and proso millet," in Progress in New Crops, ed. J. Janick (Alexandria: ASHS Press), 182-190.

Baltensperger, D. D. (2002). "Progress with proso, pearl and other millets," in Trends in New Crops and New Uses, eds J. Janick and A. Whipkey (Alexandria: ASHS Press), 100-103. 
Baltensperger, D. D., Nelson, L. A., and Frickel, G. E. (1995b). Registration of 'Earlybird' proso millet. Crop Sci. 35, 1204-1205.

Baltensperger, D. D., Nelson, L. A., Frickel, G. E., and Anderson, R. L. (1995c). Registration of 'Huntsman' proso millet. Crop Sci. 35:941.

Baltensperger, D. D., Nelson, L. A., Frickel, G. E., and Anderson, R. L. (1997). Registration of 'Sunrise' proso millet. Crop Sci. 37:1380. doi: 10.2135/ cropsci1997.0011183X003700040061x

Berglund, D. R. (2007). Proso Millet in North Dakota. Fargo, ND: North Dakota State University.

Bettinger, R. L., Barton, L., and Morgan, C. (2010a). The origins of food production in north China: a different kind of agricultural revolution. Evol. Anthropol. 19, 9-21. doi: 10.1002/evan.20236

Bettinger, R. L., Barton, L., Morgan, C., Chen, F., Wang, H., Guilderson, T. P., et al. (2010b). The transition to agriculture at Dadiwan, People's Republic of China. Curr. Anthropol. 51, 703-714.

Bettinger, R. L., Barton, L., Richerson, P. J., Boyd, R., Wang, H., and Choi, W. (2007). The transition to agriculture in northwestern China. Dev. Quat. Sci. 9, 83-101.

Boivin, N., Fuller, D. Q., and Crowther, A. (2012). Old World globalization and the Columbian exchange: comparison and contrast. World Archaeol. 44, 452-469. doi: 10.1080/00438243.2012.729404

Bouis, H. E. (2000). Enrichment of food staples through plant breeding: a new strategy for fighting micronutrient malnutrition. Nutrition 16, 701-704. doi: 10.1016/S0899-9007(00)00266-5

Castro, K. (2013). Evaluation of Millet (Various Species) Grain from US as a Pathway for Regulated Weeds. Ottawa, ON: Canadian Food Inspection Agency. Plant Biotechnology Risk Assessment Unit, 1-33.

Ceccarelli, S., and Grando, S. (1996). Drought as a challenge for the plant breeder. Plant Growth Regul. 20, 149-155. doi: 10.1007/BF00024011

CFC and ICRISAT (2004). "Alternative uses of sorghum and pearl millet in Asia," in Proceedings of the Expert Meeting, ICRISAT, Ptanacheru, Andhra Pradesh, India, 1-4July 2003: CFC Technical paper no. 34, (Amsternam: Common Fund for Commodities), 364.

Changmei, S., and Dorothy, J. (2014). Millet-the frugal grain. Int. J. Sci. Res. Rev. 3, $75-90$.

Chen, F. H., Dong, G. H., Zhang, D. J., Liu, X. Y., Jia, X., An, C. B., et al. (2015). Agriculture facilitated permanent human occupation of the Tibetan Plateau after 3600 BP. Science 347, 248-250. doi: 10.1126/science. 1259172

Cho, Y. I., Chung, J. W., Lee, G. A., Ma, K.-H., Dixit, A., Gwag, J.-G., et al. (2010). Development and characterization of twenty-five new polymorphic microsatellite markers in proso millet (Panicum miliaceum L.). Genes Genomics 32, 267-273. doi: 10.1007/s13258-010-0007-8

Colosi, J. C., and Schaal, B. A. (1997). Wild proso millet (Panicum miliaceum) is genetically variable and distinct from crop varieties of proso millet. Weed Sci. $45,509-518$.

Coulibaly, A., Kouakou, B., and Chen, J. (2011). Phytic acid in cereal grains: structure, healthy or harmful ways to reduce phytic acid in cereal grains and their effects on nutritional quality. Am. J. Plant Nutr. Fertil. Technol. 1, 1-22. doi: 10.3923/ajpnft.2011.1.22

Dai, H., Zhang, P., Lu, C., Jia, G., Song, H., Ren, X., et al. (2011). Leaf senescence and reactive oxygen species metabolism of broomcorn millet (Panicum miliaceum L.) under drought condition. Aust. J. Crop Sci. 5, 1655-1660.

Devi, P. B., Vijayabharathi, R., Sathyabama, S., Malleshi, N. G., and Priyadarisini, V. B. (2014). Health benefits of finger millet (Eleusine coracana L.) polyphenols and dietary fiber: a review. J. Food Sci. Technol. 51, 1021-1040. doi: 10.1007/ s13197-011-0584-9

Dvořáková, Z., Čepková, P. H., Janovská, D., Viehmannová, I., Svobodová, E., Cusimamani, E. F., et al. (2015). Comparative analysis of genetic diversity of 8 millet genera revealed by ISSR markers. Emirates J. Food Agric. 27, 617-628. doi: 10.9755/ejfa.2015.04.077

Dwivedi, S., Upadhyaya, H., Senthilvel, S., Hash, C., Fukunaga, K., Diao, X., et al. (2012). "Millets: genetic and genomic resources," in Plant Breeding Reviews, Vol. 35, ed. J. Janick (Hoboken, NJ: John Wiley and Sons Inc), 247-375.

Emendack, Y., Herzog, H., Götz, K.-P., and Malinowski, D. P. (2011). Mid-season water stress on yield and water use of millet (Panicum miliaceum) and sorghum (Sorghum bicolor L. Moench). Aust. J. Crop Sci. 5, 1486-1492.
Frachetti, M. D., Spengler, R. N., Fritz, G. J., and Mar'yashev, A. N. (2010). Earliest direct evidence for broomcorn millet and wheat in the central Eurasian steppe region. Antiquity 84, 993-1010. doi: 10.1017/S0003598X0006703X

Fuller, D. Q. (2006). A Millet Atlas: Some Identification Guidance. London: University College London.

Gélinas, P., McKinnon, C. M., Mena, M. C., and Méndez, E. (2008). Gluten contamination of cereal foods in Canada. Int. J. Food Sci. Technol. 43, 12451252. doi: 10.1111/j.1365-2621.2007.01599.x

Goron, T. L., and Raizada, M. N. (2015). Genetic diversity and genomic resources available for the small millet crops to accelerate a New Green Revolution. Front. Plant Sci. 6:157. doi: 10.3389/fpl.2015.00157

Graybosch, R. A., and Baltensperger, D. D. (2009). Evaluation of the waxy endosperm trait in proso millet (Panicum miliaceum). Plant Breed. 128, 70-73. doi: 10.1111/j.1439-0523.2008.01511.x

Guedes, J. D. A. (2015). Rethinking the spread of agriculture to the Tibetan Plateau. Holocene 25, 1498-1510. doi: 10.1177/0959683615585835

Guedes, J. D. A., Bocinsky, R. K., and Butler, E. E. (2015a). Comment on "Agriculture facilitated permanent human occupation of the Tibetan Plateau after 3600 BP.” Science 348, 872. doi: 10.1126/science.aaa4819

Guedes, J. D. A., Lu, H., Hein, A. M., and Schmidt, A. H. (2015b). Early evidence for the use of wheat and barley as staple crops on the margins of the Tibetan Plateau. Proc. Natl. Acad. Sci. U.S.A. 112, 5625-5630. doi: 10.1073/pnas. 1423708112

Guedes, J. D. A., Lu, H., Li, Y., Spengler, R. N., Wu, X., and Aldenderfer, M. S. (2014). Moving agriculture onto the Tibetan plateau: the archaeobotanical evidence. Archaeol. Anthropol. Sci. 6, 255-269. doi: 10.1007/s12520-0130153-4

Gupta, S., Shrivastava, S. K., and Shrivastava, M. (2014). Proximate composition of seeds of hybrid varieties of minor millets. Int. J. Res. Eng. Technol. 3, 687-693. doi: 10.15623/ijret.2014.0302122

Hardman, L. H. (1990). Varietal Trials of Farm Crops. Minnesota Report 24. Minneapolis, MN: University of Minnesota.

He, J., Zhao, X., Laroche, A., Lu, Z.-X., Liu, H., and Li, Z. (2014). Genotyping-bysequencing (GBS), an ultimate marker-assisted (MAS) tool to accelerate plant breeding. Front. Plant Sci. 5:484. doi: 10.3389/fpls.2014.00484

Herdrich, N. (2001). Grower Experiences with Millet in Eastern Washington, 19971999. Pullman, WA: Washington State University.

Hu, X., Wang, J., Lu, P., and Zhang, H. (2009). Assessment of genetic diversity in broomcorn millet (Panicum miliaceum L.) using SSR markers. J. Genet. Genomics 36, 491-500. doi: 10.1016/S1673-8527(08)60139-3

Hu, Y. G., Zhu, J., Liu, F., Zhang, Z., Chai, Y., and Weining, S. (2008). Genetic diversity among Chinese landraces and cultivars of broomcorn millet (Panicum miliaceum) revealed by the polymerase chain reaction. Ann. Appl. Biol. 153, 357-364. doi: 10.1111/1744-7348.2008.00263.x

Hulse, J. H., Laing, E. M., and Pearson, O. E. (1980). Sorghum and the Millets: Their Composition and Nutritive Value. London: Academic Press, 187-193.

Hunt, H. V., Badakshi, F., Romanova, O., Howe, C. J., Jones, M. K., and HeslopHarrison, J. S. P. (2014). Reticulate evolution in Panicum (Poaceae): the origin of tetraploid broomcorn millet, P. miliaceum. J. Exp. Bot. 65, 3165-3175. doi: $10.1093 / \mathrm{jxb} / \mathrm{eru} 161$

Hunt, H. V., Campana, M. G., Lawes, M. C., Park, Y.-J., Bower, M. A., Howe, C. J., et al. (2011). Genetic diversity and phylogeography of broomcorn millet (Panicum miliaceum L.) across Eurasia. Mol. Ecol. 20, 4756-4771. doi: 10.1111/ j.365-294X.2011.05318.x

Hunt, H. V., Denyer, K., Packman, L. C., Jones, M. K., and Howe, C. J. (2010). Molecular basis of the waxy endosperm starch phenotype in broomcorn millet (Panicum miliaceum L.). Mol. Biol. Evol. 27, 1478-1494. doi: 10.1093/molbev/ msq040

Hunt, H. V., Moots, H. M., Graybosch, R. A., Jones, H., Parker, M., Romanova, O., et al. (2012). Waxy phenotype evolution in the allotetraploid cereal broomcorn millet: mutations at the GBSSI locus in their functional and phylogenetic context. Mol. Biol. 30, 109-122. doi: 10.1093/molbev/mss209

Hunt, H. V., Vander Linden, M., Liu, X., Motuzaite-Matuzeviciute, G., Colledge, S., and Jones, M. K. (2008). Millets across Eurasia: chronology and context of early records of the genera Panicum and Setaria from archaeological sites in the Old World. Veg. Hist. Archaeobot. 17, 5-18. doi: 10.1007/s00334-0080187-1 
Jia, G. L., Dai, H. P., Feng, B. L., Zhang, S. Q., and Zhang, S. W. (2008). Biochemical characteristics in broomcorn millet (Panicum miliaceum L.) seedlings under PEG simulated drought stress. Acta Bot. Boreali Occidentalia Sin. 28, 2-73.

Kalinova, J., and Moudry, J. (2006). Content and quality of protein in proso millet (Panicum miliaceum L.) varieties. Plant Foods Hum. Nutr. 61, 45-49. doi: 10.1007/s11130-006-0013-9

Karam, D., Westra, P., Nissen, S. J., Ward, S. M., and Figueiredo, J. E. F. (2004). Genetic diversity among proso millet (Panicum miliaceum) biotypes assessed by AFLP techniques. Planta Daninha 22, 167-174. doi: 10.1590/S010083582004000200001

Karam, D., Westra, P., Nissen, S. J., Ward, S. M., and Figueiredo, J. E. F. (2006). Assessment of silver-stained AFLP markers for studying DNA polymorphism in proso millet (Panicum miliaceum L.). Rev. Brasil Bot. 29, 609-615. doi: 10.1590/S0100-84042006000400011

Karyudi and Fletcher, R. J. (2002). Osmoregulation in birdseed millet under conditions of water stress. I. Variation in Setaria italica and Panicum miliaceum. Euphytica 125, 337-348. doi: 10.1023/A:1016073910886

Koenig, R., Schroeder, K., Carter, A., Pumphrey, M., Paulitz, T., Campbell, K., et al. (2011). Soil Acidity and Aluminum Toxicity in the Palouse Region of the Pacific Northwest. Pullman, WA: Washington State University.

Kole, C., Muthamilarasan, M., Henry, R., Edwards, D., Sharma, R., Abberton, M., et al. (2015). Application of genomics-assisted breeding for generation of climate resilient crops: progress and prospects. Front. Plant Sci. 6:563. doi: 10.3389/fpls.2015.00563

Konstantinov, S. I., Linnik, V. M., Shapina, L. Y., and Grigorashchenko, L. V. (1991). Breeding proso millet for resistance to diseases. Urozha $\breve{i} i$ adaptivny potentsial ekologicheskoii sistemy polya 112-117.

Kothari, S. L., Kumar, S., Vishnoi, R. K., Kothari, A., and Watanabe, K. N. (2005). Applications of biotechnology for improvement of millet crops: review of progress and future prospects. Plant Biotechnol. 22, 81-88. doi: 10.5511/ plantbiotechnology.22.81

Krishna, K. R. (2013). Agroecosystems: Soils, Climate, Crops, Nutrient Dynamics and Productivity. Boca Raton, FL: CRC Press.

Kubešová, M., Moravcová, L., Suda, J., Jarošík, V., and Pyšek, P. (2010). Naturalized plants have smaller genomes than their non-invading relatives: a flow cytometric analysis of the Czech alien flora. Preslia 82, 81-96.

Kumari, K., Muthamilarasan, M., Misra, G., Gupta, S., Subramanian, A., Parida, S. K., et al. (2013). Development of eSSR-markers in Setaria italica and their applicability in studying genetic diversity, cross-transferability and comparative mapping in millet and non-millet species. PLoS ONE 8:e67742. doi: 10.1371/ journal.pone.0067742

Kumari, P. L., and Sumathi, S. (2002). Effect of consumption of finger millet on hyperglycemia in non-insulin dependent diabetes mellitus (NIDDM) subjects. Plant Foods Hum. Nutr. 57, 205-213. doi: 10.1023/A:1021805028738

Kushwaha, H., Jillo, K. W., Singh, V. K., Kumar, A., and Yadav, D. (2015). Assessment of genetic diversity among cereals and millets based on the PCR amplification using Dof (DNA binding with One Finger) transcription factor gene-specific primers. Plant Syst. Evol. 301, 833-840. doi: 10.1007/s00606-0141095-8

Lágler, R., Gyulai, G., Humphreys, M., Szabó, Z., Horváth, L., Bittsánszky, A., et al. (2005). Morphological and molecular analysis of common millet (P. miliaceum) cultivars compared to a DNA sample from the 15th century (Hungary). Euphytica 146, 77-85. doi: 10.1007/s10681-005-5814-7

Lata, C. (2015). Advances in omics for enhancing abiotic stress tolerance in millets. Proc. Indian Natl. Sci. Acad. 81, 397-417.

Liang, S., Yang, G., and Ma, Y. (2010). Chemical characteristics and fatty acid profile of foxtail millet bran oil. J. Am. Oil Chem. Soc. 87, 63-67. doi: 10.1007/ s11746-009-1475-3

Lin, F., Hu, Y., Song, G., and He, B. (2006a). Analysis on the responsive genes during drought and rehydration in broomcorn millet (Panicum miliaceum L.) by means of cDNA-AFLP. Agric. Res. Arid Areas 3:19.

Lin, F., Hu, Y., Song, G., Zhang, H., Liu, T., and He, B. (2006b). Isolation and analysis of genes induced by rehydration after serious drought in broomcorn millet (Panicum miliaceum L.) by SSH. Chin. J. Agric. Biotechnol. 3, 237-242. doi: 10.1079/CJB2006119

Lin, F., Wang, S., Hu, Y., and He, B. (2008). Cloning of a S-adenosylmethionine synthetase gene from broomcorn millet (Panicum miliaceum L.) and its expression during drought and re-watering. Acta Agron. Sin. 34, 777-782. doi: 10.3724/SP.J.1006.2008.00777

Liu, M., Xu, Y., Zhang, S., Wang, Y., and Lu, P. (2016). Genetic diversity and population structure of broomcorn millet (Panicum miliaceum L.) cultivars and landraces in China based on microsatellite markers. Int. J. Mol. Sci. 17, 370-388. doi: 10.3390/ijms1703 0370

Lorenz, K., and Dilsaver, W. (1980). Proso millets. Milling characteristics, proximate compositions, nutritive value of flours. Cereal Chem. 57, 16-20.

Lu, H., Zhang, J., Liu, K. B., Wu, N., Li, Y., Zhou, K., et al. (2009). Earliest domestication of common millet (Panicum miliaceum) in East Asia extended to 10,000 years ago. Proc. Natl. Acad. Sci. U.S.A. 106, 7367-7372. doi: 10.1073/ pnas.0900158106

Lyon, D. J., Burgener, P. A., and DeBoer, K. (2008b). EC08-137 Producing and Marketing Proso Millet in the Great Plains. Lincoln, NB: University of NebraskaLincoln.

Lyon, D. J., Burgener, P. A., DeBoer, K. L., Harveson, R. M., Hein, G. L., Hergert, G. W., et al. (2008a). Proso Millet in the Great Plains. Lincoln, NB: University of Nebraska Extension Service.

Marcott, S. A., Shakun, J. D., Clark, P. U., and Mix, A. C. (2013). A reconstruction of regional and global temperature for the past 11,300 years. Science 339, 1198-1201. doi: 10.1126/science.1228026

Matsuura, A., Tsuji, W., An, P., Inanaga, S., and Murata, K. (2012). Effect of preand post-heading water deficit on growth and grain yield of four millets. Plant Prod. Sci. 15, 323-331. doi: 10.1626/pps.15.323

McCool, D. K., and Roe, R. D. (2005). Long-Term Erosion Trends on Cropland in the Pacific Northwest. St. Joseph, MI: American Society of Agricultural and Biological Engineers. doi: 10.13031/2013.20047

McDonald, M. B., and Copeland, L. O. (1997). Seed Production Principles and Practices. New York, NY: Chapman \& Hall Chapman.

McDonald, S. K., Hofsteen, L., and Downey, L. (2003). Crop Profile for Proso Millet in Colorado. USDA Crop Profiles, Regional IPM Centers. Available at: http://www.ipmcenters.org/CropProfiles/

McFarland, C., Huggins, D. R., and Koenig, R. (2015). FS170E Soil pH and Implications for Management: An Introduction (Soil Acidification Series). Pullman, WA: Washington State University, 1-7.

Miller, N. M., Spengler, R. N., and Frachetti, M. (2016). Millet cultivation across Eurasia: origins, spread, and the influence of seasonal climate. Holocene 26, 1566-1575. doi: 10.1177/0959683616641742

M'Ribu, H. K. M., and Hilu, K. W. (1994). Detection of interspecific and intraspecific variation in Panicum millets through random amplified polymorphic DNA. Theor. Appl. Genet. 88, 412-416. doi: 10.1007/BF00223653

Naylor, R. L., Falcon, W. P., Goodman, R. M., Jahn, M. M., Sengooba, T., Tefera, H., et al. (2004). Biotechnology in the developing world: a case for increased investments in orphan crops. Food Policy 29, 15-44. doi: 10.1016/j.foodpol. 2004.01.002

Newmaster, S. G., Ragupathy, S., Dhivya, S., Jijo, C. J., Sathishkumar, R., and Patel, K. (2013). Genomic valorization of the fine scale classification of small millet landraces in Southern India. Genome 56, 123-127. doi: 10.1139/gen2012-0183

Ngara, R., and Ndimba, B. (2014). Understanding the complex nature of salinity and drought-stress response in cereals using proteomics technologies. Proteomics 14, 611-621. doi: 10.1002/pmic.201300351

Nielsen, D. C., Unger, P. W., and Miller, P. R. (2005). Efficient water use in dryland cropping systems in the Great Plains. Agron. J. 97, 364-372.

Nishizawa, N., and Fudamo, Y. (1995). The elevation of plasma concentration of high-density lipoprotein chloesterol in mice fed with protein from proso millet (Panicum miliaceum). Biosci. Biotechnol. Biochem. 59, 333-335. doi: 10.1271/ bbb. 59.333

Nishizawa, N., Sato, D., Ito, Y., Nagasawa, T., Hatakeyama, Y., Choi, M. R., et al. (2002). Effects of dietary protein of proso millet on liver injury induced by D-galactosamine in rats. Biosci. Biotechnol. Biochem. 66, 92-96. doi: 10.1271/ bbb. 66.92

Obilana, A. B., and Manyasa, E. (2002). "Millets"' in Pseudocereals and Less Common Cereals, eds P. S. Belton and J. R. N. Taylor (Berlin: Springer), 177-217. 
Oelke, E. A., Oplinger, E. S., Putnam, D. H., Durgan, B. R., Doll, J. D., and Undersander, D. J. (1990). Millets: Alternative Field Crop Manual. University of Wisconsin Extension, Cooperative Extension, University of Minnesota Center for Alternative Plant and Animal Products CAPAP and the Minnesota Extension Service. Available at: https://hort.purdue.edu/newcrop/afcm/millet.html.

Pak, J. H., Kim, M. J., Kim, H. J., Shin, S. H., Seo, M. C., Oh, I. S., et al. (2012). Phylogenetic analysis of common millet (Panicum miliaceum L.) using NTS of 5S ribosomal DNA. Korean J. Breed. Sci. 44, 470-475. doi: 10.9787/kjbs.2012.44. 4.470

Pathak, H. C. (2013). Role of Millets in Nutritional Security of India. New Delhi: National Academy of Agricultural Sciences, 1-16.

Rachie, K. O. (1975). The Millets. Importance, Utilization and Outlook. Hyderabad: International Crops Research Institute for the Semi-Arid Tropics (ICRISAT).

Rajput, S. G., Harveson, T., and Santra, D. K. (2014). Development and characterization of SSR markers in proso millet (Panicum miliaceum L.) based on switchgrass genomics. Am. J. Plant Sci. 5, 175-186. doi: 10.4236/ajps.2014. 51023

Rajput, S. G., and Santra, D. K. (2016). Evaluation of genetic diversity of proso millet germplasm available in the United States using simplesequence repeat markers. Crop Sci. 56, 1-9. doi: 10.2135/cropsci2015.10. 0644

Rajput, S. G., Santra, D. K., and Schnable, J. (2016). Mapping QTLs for morphoagronomic traits in proso millet (Panicum miliaceum L.). Mol. Breed. 36, 1-18. doi: 10.1007/s11032-016-0460-4

Rao, M. V. (1989). Small Millets in Global Agriculture. The Small Millets: Their Importance, Present Status and Outlook. Delhi: Oxford and IBH Publishing Co Pvt Ltd, 9-12.

Rasmussen, P. E., Albrecht, S. L., and Smiley, R. W. (1998). Soil C and $\mathrm{N}$ changes under tillage and cropping systems in semi-arid Pacific Northwest agriculture. Soil Till. Res. 47, 197-205. doi: 10.1016/S0167-1987(98) 00106-8

Rasmussen, P. E., Collins, H. P., and Smiley, R. W. (1994). Long-Term Management Effects on Soil Productivity and Crop Yield in Semi-Arid Regions of Eastern Oregon. Corvallis, OR: Agricultural Experiment Station Bull., 675.

Ravindran, G. (1991). Studies on millets: proximate composition, mineral composition, and phytate and oxalate contents. Food Chem. 39, 99-107. doi: 10.1016/0308-8146(91)90088-6

Riley, K. W., Setharam, A., and Harinarayana, G. (1989). "Recommendations on breeding and varietal improvement. Small millets in global agriculture," in Proceedings of the First International Small Millets Workshop (New Delhi: Oxford and IBH Publishing), 29.

Rose, D. J., and Santra, D. K. (2013). Proso millet (Panicum miliaceum L.) fermentation for fuel ethanol production. Ind. Crops Prod. 43, 602-605. doi: 10.1016/j.indcrop.2012.08.010

Saha, D., Channabyre Gowda, M. V., Arya, L., Verma, M., and Bansal, K. C. (2016). Genetic and genomic resources of small millets. Crit. Rev. Plant Sci. 35, 56-79. doi: 10.1080/07352689.2016.1147907

Saleh, A. S., Zhang, Q., Chen, J., and Shen, Q. (2013). Millet grains: nutritional quality, processing, and potential health benefits. Compr. Rev. Food Sci. Food Saf. 12, 281-295. doi: 10.1111/1541-4337.12012

Salini, K., Nirmalakumari, A., Muthiah, A. R., and Senthil, N. (2010). Evaluation of proso millet (Panicum miliaceum L.) germplasm collections. Electron. J. Plant Breed. 1, 489-499.

Santra, D. K. (2013). Proso Millet Varieties for Western Nebraska. Lincoln, NE: University of Nebraska-Lincoln.

Santra, D. K., Heyduck, R. F., Baltensperger, D. D., Graybosch, R. A., Nelson, L. A., Frickel, G., et al. (2015). Registration of 'Plateau'waxy (amylose-free) proso millet. J. Plant Regist. 9, 41-43. doi: 10.3198/jpr2013.11. $0067 \mathrm{crc}$

Sateesh, P. V. (2010). Millets: Future of Food and Farming. Hyderabad: Millet Network of India Deccan Development Society FIAN, 2-9.

Schaible, G., and Aillery, M. (2012). Water Conservation in Irrigated Agriculture: Trends and Challenges in the Face of Emerging Demands. Washington, DC: U.S. Department of Agriculture (USDA) - Economic Research Service (ERS).

Schillinger, W. F., Papendick, R. I., Guy, S. O., Rasmussen, P. E., and Van Kessel, C. (2003). "Dryland Cropping in the Western United States. Chap. 2Conservation tillage systems and equipment," in Pacific Northwest Conservation
Tillage Handbook Series No. 28, (Pullman, WA: Washington State University), $1-19$.

Schoth, H. A., and Rampton, H. H. (1939). Sudan Grass, Millets and Sorghum in Oregon. Corvallis, OR: USDA/Oregon Agricultural Experiment Station.

Seghatoleslami, M. J., Kafi, M., and Majidi, E. (2008). Effect of drought stress at different growth stages on yield and water use efficiency of five proso millet (Panicum miliaceum L.) genotypes. Pak. J. Bot. 40, 1427-1432.

Shahidi, F., and Chandrasekara, A. (2013). Millet grain phenolics and their role in disease risk reduction and health promotion: a review. J. Funct. Foods 5, 570-581. doi: 10.1016/j.jff.2013.02.004

Shobana, S., and Malleshi, N. G. (2007). Preparation and functional properties of decorticated finger millet (Eleusine coracana). J. Food Eng. 79, 529-538. doi: 10.1016/j.jfoodeng.2006.01.076

Thompson, T. (2009). "The nutritional quality of gluten-free foods," in Glutenfree Food Science and Technology, ed. E. Gallagher (Hoboken, NJ: Blackwell Publishing Ltd), 42-51.

Trivedi, A. K., Arya, L., Verma, M., Tyagi, R. K., and Hemantaranjan, A. (2015). Genetic variability in proso millet (Panicum miliaceum) germplasm of Central Himalayan Region based on morpho-physiological traits and molecular markers. Acta Physiol. 37, 23-38. doi: 10.1007/s11738-014-1770-y

Upadhyaya, H. D., Sharma, S., Gowda, C. L. L., Reddy, G., and Singh, S. (2011). Developing proso millet (Panicum miliaceum L.) core collection using geographic and morpho-agronomic data. Crop Pasture Sci. 62, 383-389. doi: 10.1071/CP10294

Upadhyaya, H. D., Yadav, D., Dronavalli, N., Gowda, C. L. L., and Singh, S. (2010). Mini core germplasm collections for infusing genetic diversity in plant breeding programs. Electron. J. Plant Breed. 1, 1294-1309.

USDA FAS (2012). Increased US Millet Exports to the Netherlands. Global Agricultural Information Network Report Number: NL2009. Washington, DC: USDA - Foreign Agricultural Service, 1-2.

USDA-NASS (2016). Crop Production 2015 Summary. Washington, DC: United States Department of Agriculture National and Agricultural Statistics Service.

Varshney, R. K., Glaszmann, J. C., Leung, H., and Ribaut, J. M. (2010). More genomic resources for less-studied crops. Trend Biotechnol. 28, 452-460. doi: 10.1016/j.tibtech.2010.06.007

Verma, V., and Patel, S. (2012). Nutritional security and value added products from finger millets (ragi). J. Appl. Chem. 1, 485-489.

Wang, W., Vinocur, B., and Altman, A. (2003). Plant responses to drought, salinity and extreme temperatures: towards genetic engineering for stress tolerance. Planta 218, 1-14. doi: 10.1007/s00425-003-1105-5

Weber, S. A. (1991). Plants and Harappan Subsistence: An Example of Stability and Change from Rojdi. Boulder, CO: Westview Press.

Weining, S., and Henry, R. (1995). Molecular analysis of the DNA polymorphism of wild barley (Hordeum spontaneum) using the polymerase chain reaction. Genet. Res. Crop Evol. 42, 273-281. doi: 10.1007/BF02431262

Weining, S., and Langridge, P. (1991). Identification and mapping polymorphism in cereals based on polymerase chain reaction. Theor. Appl. Genet. 82, 209-216. doi: 10.1007/BF00226215

Wen, Y., Liu, J., Meng, X., Zhang, D., and Zhao, G. (2014). Characterization of proso millet starches from different geographical origins of China. Food Sci. Biotechnol. 23, 1371-1377. doi: 10.1007/s10068-014-0188-z

Williams, J. D., Wuest, S. B., and Long, D. S. (2014). Soil and water conservation in the Pacific Northwest through no-tillage and intensified crop rotations. J. Soil Water Conserv. 69, 495-504. doi: 10.2489/jswc.69.6.495

Williams, M. M., Boydston, R. A., and Davis, A. S. (2007). Wild proso millet (Panicum miliaceum) suppressive ability among three sweet corn hybrids. Weed Sci. 55, 245-251. doi: 10.1614/WS-06-123.1

Wilson, R. L., and Burton, R. L. (1980). Feeding and oviposition of selected insect pests on proso millet cultivars. J. Econ. Entomol. 73, 817-819. doi: 10.1093/jee/ 73.6.817

Wilson, R. L., and Courteau, J. B. (1984). Search of plant introduction proso millets for fall armyworm resistance. J. Econ. Entomol. 77, 171-173. doi: 10.1093/jee/ 77.1.171

Wright, S. F., and Anderson, R. L. (2000). Aggregate stability and glomalin in alternative crop rotations for the central Great Plains. Biol. Fertil. Soils 31, 249-253. doi: 10.1007/s003740050653 
Wu, Y.-J., Du, J.-F., Wang, X.-L., Fang, X.-F., Shan, W.-X., and Liang, Z.-S. (2012). Computational prediction and experimental verification of miRNAs in Panicum miliaceum L. Sci. China Life Sci. 55, 807-817. doi: 10.1007/s11427012-4367-y

Yang, X., Wan, Z., Perry, L., Lu, H., Wang, Q., Zhao, C., et al. (2012). Early millet use in northern China. Proc. Natl. Acad. Sci. U.S.A. 109, 3726-3730. doi: 10.1073/pnas.1115430109

Yue, H., Wang, L., Liu, H., Yue, W., Du, X., Song, W., et al. (2016a). De novo assembly and characterization of the transcriptome of broomcorn millet (Panicum miliaceum L.) for gene discovery and marker development. Front. Plant Sci. 7:1083. doi: 10.3389/fpls.2016. 01083

Yue, H., Wang, M., Liu, S., Du, X., Song, W., and Nie, X. (2016b). Transcriptome-wide identification and expression profiles of the WRKY transcription factor family in broomcorn millet (Panicum miliaceum L.). BMC Genomics 17:343. doi: 10.1186/s12864-0162677-3

Zhang, L., Liu, R., and Niu, W. (2014). Phytochemical and antiproliferative activity of proso millet. PLOS ONE 9:e104058. doi: 10.1371/journal.pone. 0104058

Zhang, P., Feng, B., Wang, P., Dai, H., Song, H., Gao, X., et al. (2012a). Leaf senescence and activities of antioxidant enzymes in different broomcorn millet (Panicum miliaceum L.) cultivars under simulated drought condition. J. Food Agric. Environ. 10, 438-444.
Zhang, P., Feng, B., Wang, P., Gao, X., Gao, J., Song, H., et al. (2012b). Study on identification of drought-resistance indexes at seedling state in broomcorn millet under PEG stress. J. China Agric. Univ. 1:10.

Zhao, Z. (2005). Palaeoethnobotany and its new achievements in China. Kaogu 2005:42-49.

Zhou, Y., Qu, Y., Zhu, M., Liu, J., Wang, Y., Song, H., et al. (2016). Genetic diversity and virulence variation of Sporisorium destruens isolates and evaluation of broomcorn millet for resistance to head smut. Euphytica 211, 59-70. doi: 10. 1007/s10681-016-1723-1

Zohary, D., Hopf, M., and Weiss, E. (2012). Domestication of Plants in the Old World: The Origin and Spread of Domesticated Plants in Southwest Asia, Europe, and the Mediterranean Basin. New York, NY: Oxford University Press.

Conflict of Interest Statement: The authors declare that the research was conducted in the absence of any commercial or financial relationships that could be construed as a potential conflict of interest.

Copyright (c) 2017 Habiyaremye, Matanguihan, d'Alpoim Guedes, Ganjyal, Whiteman, Kidwell and Murphy. This is an open-access article distributed under the terms of the Creative Commons Attribution License (CC BY). The use, distribution or reproduction in other forums is permitted, provided the original author(s) or licensor are credited and that the original publication in this journal is cited, in accordance with accepted academic practice. No use, distribution or reproduction is permitted which does not comply with these terms. 